NBER WORKING PAPER SERIES

\title{
CAREER TECHNICAL EDUCATION AND LABOR MARKET OUTCOMES: EVIDENCE FROM CALIFORNIA COMMUNITY COLLEGES
}

\author{
Ann Huff Stevens \\ Michal Kurlaender \\ Michel Grosz \\ Working Paper 21137 \\ http://www.nber.org/papers/w21137 \\ NATIONAL BUREAU OF ECONOMIC RESEARCH \\ 1050 Massachusetts Avenue \\ Cambridge, MA 02138 \\ April 2015, Revised February 2018
}

The research reported here was supported in part by the Institute of Education Sciences, U.S. Department of Education, through Grant R305C110011 to Teachers College, Columbia University. The opinions expressed are those of the authors and do not represent views of the Institute or the U.S. Department of Education. We gratefully acknowledge the California Community Colleges Chancellor's Office for providing us with data access, technical support, and expertise. We are also appreciative of financial support from the Center for Poverty Research at UC Davis, funded by the U.S. Department of Health and Human Services, Office of the Assistant Secretary for Planning and Analysis (ASPE), the Interdisciplinary Frontiers in the Humanities and Arts Program at UC Davis, and from the Smith Richardson Foundation. The authors are responsible for all errors. The opinions expressed are those of the authors alone and not those of agencies providing data or funding, nor of the National Bureau of Economic Research.

NBER working papers are circulated for discussion and comment purposes. They have not been peer-reviewed or been subject to the review by the NBER Board of Directors that accompanies official NBER publications.

(C) 2015 by Ann Huff Stevens, Michal Kurlaender, and Michel Grosz. All rights reserved. Short sections of text, not to exceed two paragraphs, may be quoted without explicit permission provided that full credit, including ( $)$ notice, is given to the source. 
Career Technical Education and Labor Market Outcomes: Evidence from California Community Colleges

Ann Huff Stevens, Michal Kurlaender, and Michel Grosz

NBER Working Paper No. 21137

April 2015, Revised February 2018

JEL No. I24,I26

\begin{abstract}
Career technical education (CTE) programs at community colleges are increasingly seen as an attractive alternative to four-year colleges, yet little systematic evidence exists on the returns to specific certificates and degrees. We estimate returns to CTE programs using administrative data from the California Community College system linked to earnings records. We employ estimation approaches including individual fixed effects and individual-specific trends, and find average returns to CTE certificate and degrees that range from 14 to 45 percent. The largest returns are for programs in the healthcare sector; estimated returns in non-health related programs range from 15 to 23 percent.

Ann Huff Stevens

Department of Economics

One Shields Avenue

University of California, Davis

Davis, CA 95616

and NBER

annstevens@ucdavis.edu

Michal Kurlaender

University of California, Davis

One Shields Avenue

School of Education

Davis, CA 95616

mkurlaender@ucdavis.edu

Michel Grosz

University of California, Davis

One Shields Avenue

Department of Economics

Davis, CA 95616

mgrosz@ucdavis.edu
\end{abstract}




\section{Introduction}

For the past half-century, the earnings of Americans with less than a four-year college degree have stagnated or fallen. Despite widespread increases in postsecondary participation, the fraction of Americans completing bachelor's degrees has not risen substantially in decades, and is declining for some groups (National Center for Education Statistics, 2016; Bailey \& Dynarski, 2011; Turner, 2004). Although many efforts have focused on increasing educational attainment, it is clear that encouraging college enrollment in traditional academic pathways is not sufficient. Important demographic and labor market changes have demanded a more skilled workforce with increased postsecondary training. Vocational or career technical education (CTE) programs are often recognized as an important part of the solution to workforce training needs, but returns to specific CTE programs have rarely been systematically or convincingly evaluated.

Many CTE programs are offered through public state community college systems. These community colleges are the primary point of access to higher education for many Americans. In California, the setting for this study, two-thirds of all college students attend a community college. As the largest public community college system, one-sixth of all community college students in the nation are enrolled at a California community college. Over the years, California's community colleges have grown and have been applauded for remaining affordable, open-access institutions, but also continually criticized for producing weak outcomes, in particular low degree receipt and low transfer rates to four-year institutions (Sengupta and Jepsen, 2006; Shulock and Moore, 2007). Moreover, CTE programs within California's community colleges, which often attract students without an explicit goal to transfer to bachelor's-granting institutions, have often been omitted from these discussions (Shulock, Moore, and Offenstein, 2011; Shulock and Offenstein, 2012). 
This paper takes a major step toward filling the gap in the literature on returns to CTE progams in higher education. Using longitudinal administrative data from the largest community college system in the nation, we estimate the returns to specific CTE certificates and degrees. By taking advantage of the fact that the vast majority of CTE students have substantial preenrollment earnings histories, we are able to present detailed estimates of the labor market returns to completing CTE certificates and associate degrees. We use these data to estimate models that control for both fixed unobservable factors that may be correlated with certificate or degree completion, and for similar factors that change at a constant rate over time. The fixed effects approach produces estimates of the return to certificates and degrees relative to earnings in the absence of degree receipt, using individuals' own pre-enrollment earnings as the critical control variables. We utilize a control group of individuals enrolling but not completing degrees and certificates, which, in the fixed effects setting, help to identify common year, age, and enrollment effects. Estimates based on a subset of our data that use parental background and high school test scores to control for heterogeneity in OLS regressions produce slightly larger estimates than our fixed effects models, confirming the importance of controlling for unobservable, fixed factors.

Our approach also addresses the tremendous heterogeneity in types of program offerings within the broad grouping of CTE programs, and we separately analyze fields that include a wide range of courses preparing students for careers as police, prison officers, health care providers, or construction workers, among others. We find returns to CTE programs that range from 14 percent (for certificates of less than 18 units) to 45 percent (for associate degrees). We find especially large returns for programs in the health sector, ranging from 12 to 99 percent. Results are not sensitive to our specific choices involving a control group or control variables. 


\section{Prior Research on the Returns to Postsecondary Schooling}

As part of the large literature on returns to higher education, a growing number of authors have focused on community colleges, with fewer focused on CTE programs. On the broader topic of returns to community college enrollment and awards, for example, Belfield and Bailey (2011) review a number of studies over the past several decades. As these authors note, the vast majority of those studies are correlational in nature, comparing the earnings of those who do and do not attend or complete community college programs. ${ }^{1}$ Many of these studies fail to control for potentially important sources of bias, including ability bias, or are inattentive to more general contamination of the estimates by correlation between degree completion or attendance and unobserved personal characteristics. Thus, while there are many examples of studies that show higher earnings associated with community college attendance, until recently there has been little evidence establishing a causal connection between community college programs and earnings. Even less such evidence exists for CTE programs within community colleges.

Kane and Rouse (1995) estimated returns to accrued credits (and degrees) at community colleges and found returns to coursework at exclusively vocational colleges separately, but did not separate vocational and traditional academic programs within community colleges. They found returns to credits earned at vocational schools that were similar to or smaller than returns to credits from two-year colleges. Bailey et al. (2004a) found that CTE associate degrees produce larger gains than academic associate degrees, using a standard OLS framework with no controls for ability bias or other unobservables. Leigh and Gill (1997) focused on returning adults, using

\footnotetext{
${ }^{1}$ For examples of these observational studies comparing those with and without community college credits or degrees see Rosenbaum and Rosenbaum (2013), Belfield and Bailey (2011), or Bailey et al. (2004b).
} 
an OLS framework with a rich set of control variables, and found positive returns to community college degrees, similar to the more traditionally aged students studied by Kane and Rouse (1995).

An important advance in this literature came from Jacobson, LaLonde, and Sullivan (JLS, 2005) who evaluated the return to CTE programs within Washington State community colleges. Their innovation was to use both individual fixed effects and individual-specific earnings trends to control for unobservables that are correlated with both earnings (levels and trends) and the likelihood of completing training. Surprisingly, most studies following JLS (2005) have not included or tested for robustness to individual-specific trends.

Beyond the methods used, the study by JLS is important for two additional reasons, both of which relate to and motivate our study. First, these authors recognized that CTE programs provide an opportunity for causal identification of the return to CTE that is not often available for higher education studies more generally. The use of fixed effects and individual-specific trends depends critically on having multiple earnings observations prior to enrollment in the program. For students pursuing traditional academic paths, this is often impossible since they have very limited earnings observations prior to enrolling in college. Second, JLS are among the first to document that there may be substantial heterogeneity in returns across different programs or disciplines in the CTE realm. They found, for example, returns of approximately $14 \%$ for men and $30 \%$ for women in "technically oriented math and science courses" in the CTE realm, but essentially no return for other CTE coursework. The sample for their study was notably a group of high tenure displaced workers and therefore may not apply to the broader group of students in CTE programs. 
More recently, a number of studies have made use of administrative earnings data linked to community college records to estimate returns to a community college education. These studies have been far more inclusive of CTE programs, though not typically focusing on CTE programs specifically. Jepsen, Troske, and Coomes (2014) estimated models with individual fixed effects and found positive returns to both CTE associate degrees and shorter "diplomas" for men, but less evidence of returns to diplomas for women. They did not include individualspecific trends, but did interact observable characteristics with trends as a substitute for more fully controlling for time-varying unobservables. They did not present estimates for specific programs of study within the broader category of CTE. Bahr et al. (2015) followed a similar approach using data from Michigan, and estimated returns separately for some specific CTE awards, including shorter certificates and associate degrees. However, small sample sizes within individual study areas limited Bahr et al. (2015) to estimate returns for a smaller set of shorterterm CTE certificates, and those estimated often had large confidence intervals.

A pattern of heterogeneous effects across programs was also found in Dadgar and Trimble (2016) using data from the state of Washington. They showed, surprisingly, negative and significant effects of short-term certificates on earnings for women, and no statistically significant returns for men, but positive significant returns of long-term certificates for women and no significant returns to for men. Their estimates for field-specific certificates were also limited by small samples, making it difficult to draw sharp conclusions. Finally, Xu and Trimble (2016) showed positive and significant returns, on average, to both short- and longer-term certificates in North Carolina and Virginia. When they disaggregated by field of study, results were mixed, with both positive and negative statistically significant effects depending on the field of study. Both of these studies used fixed effects models and a control group of students 
enrolling in courses but not completing certificates or degrees. They did not, however, examine robustness to individual-specific trends.

A final study, similar to many of those described above, is important because its comparison of standard cross-sectional and fixed effects estimates makes clear that methodology can make a substantive difference. Liu, Belfield, and Trimble (2015) showed that OLS estimates with controls for ability and demographics produce negative, and sometimes significant, effects of short-term CTE certificates. Interestingly, models including fixed effects suggested positive and significant effects for the same programs. This pattern of results suggests negative selection of individuals (in terms of earnings) into certificate programs. This implies that it may be very important, particularly in the case of short-term CTE programs, to control for earnings prior to enrollment in a flexible way. ${ }^{2}$

Finally, an unpublished study by Bahr (2016), developed simultaneously with ours, also uses administrative data from California Community Colleges, and a fixed effects approach. Bahr's findings for CTE programs appear to be qualitatively similar to ours. Courses of study and award types for which we find the largest returns also show large returns in Bahr's work, and similarly for many of those with smaller returns. Our work differs from Bahr's not only in our closer focus on CTE programs, but also in several aspects of our econometric specifications. Notably, the fixed effects approach used in both studies requires earnings prior to enrollment to control for individual productive ability. We make the case below that these pre-enrollment earnings are widely available among our sample of CTE students, but may not be for more

\footnotetext{
${ }^{2}$ Another similar, unpublished, study in this area is by Bettinger and Soliz (2016), who find positive effects of subbaccalaureate degrees at Ohio postsecondary institutions, with important heterogeneity by gender, field of study, and certificate type. While they do use a fixed effects approach to control for selection bias, they lack pre-enrollment earnings data and must rely on earnings while enrolled in college to identify returns in a fixed effects setting. As the authors note, this could lead to biases in either direction.
} 
traditional academic paths. Bahr estimates returns to all community college programs, some of which are populated largely by traditional students entering the system straight from high school who cannot have much earnings history to support the fixed effects approach. ${ }^{3}$ Of course, his estimates focusing on CTE programs should not be directly affected by this concern. Bahr does not test for the existence of differential trends among award completers and non-completers prior to enrollment.

A related issue is that Bahr estimates a single equation with interaction terms to estimate returns for more than 50 different awards (both CTE and traditional academic), while we allow separate regressions for each CTE program and award length. We have replicated his approach and find estimates to be fairly sensitive to whether we estimate a single equation or separate equations for each award type, particularly when estimated using earnings levels rather than logs. We suspect this may explain many of the differences between our point estimates and Bahr's and prefer the additional flexibility of separate equations across fields. ${ }^{4}$

The literature to date, particularly recent studies that have used pre-enrollment earnings data to implement fixed effects estimators, has produced mixed results on the returns to CTE, particularly for certificates and diplomas below the associate degree level. This heterogeneity in estimated returns highlights the need for studies that can disaggregate CTE programs and estimate returns for relatively specific programs of study. In addition, short of randomization or a quasi-experimental design, recent studies show that it is important to have extensive pre-

\footnotetext{
${ }^{3}$ Bahr's Table 1, for example, shows that half of his sample is age 18 or 19 and he reports an average age at enrollment of 25 years, nearly five years lower than our average age. This difference is likely driven by the distinction between CTE students and all community college students.

${ }^{4}$ One additional difference is that Bahr allows effects to vary by years since the award was completed using a quadratic in quarters. We have estimated models that allow effects to vary over time, but use a more flexible step function. (See Appendix Table A1).
} 
enrollment earnings data and a population with substantial labor market experience before enrollment.

Our contributions in this paper fill an important gap in this literature by combining data from a large population of CTE programs including a variety of occupational fields and award lengths with longitudinal data methods that make best use of these rich data. We focus exclusively on CTE programs within the California Community College system, and the corresponding student population with substantial work experience prior to enrollment. Unlike some similar work, we look at the entire universe of students enrolling in CTE programs, rather than starting from specific categories of CTE program users such as displaced workers or welfare recipients. In addition, our access to the entire population of students in this system for 23 years allows us to provide disaggregated estimates for a wide spectrum of CTE certificates and degrees. Finally, we utilize our long time-series of earnings data to estimate models that control for both individual fixed effects and individual-specific trends, as was done by Jacobson, LaLonde, and Sullivan (2005), but not later authors. The potential importance of these controls was recently highlighted by Dynarksi, Jacob, and Kreisman (2016) who discuss the assumption of common earnings trends (conditional on fixed effects) across groups with different degree outcomes, and recommend testing the robustness of earnings results to the individuals-trends model we utilize here. This produces results that provide an estimate of the return to completing certificates and degrees (including accumulation of all of the required units), relative to their own prior earnings patterns, and adjusting for age, time and common shocks using data from individuals pursuing (but not completing) the same type of degree or certificate. 


\section{Data}

The California Community Colleges system consists of 114 campuses and is the largest public higher education system in the country, enrolling over 2.6 million students annually (Scott \& Perry, 2011). The state's large public postsecondary system of sub-baccalaureate colleges offers great individual and institutional diversity. Colleges represent urban, suburban, and rural regions of California, range in size from 1,000 to over 40,000 students enrolled each semester, and offer a wide range of CTE and traditional academic programs to a diverse set of students. CTE programs are a prominent part of the overall mission of community colleges. In a typical year in California, more than half of all awards issued are for a CTE degree, and more than 60,000 of these CTE awards are given annually in recent years. We illustrate this in Appendix Figure A1, which summarizes the number of CTE and total awards issued by California community colleges for the years covered in our sample. The top line shows all awards from the colleges for each year from 1996 to 2013, and the line immediately below shows the subset of CTE degrees. The figure also shows that these CTE awards are distributed across the various certificate and degree lengths described earlier.

We combine two sources of data for the analysis, tracking California community college students through their postsecondary schooling and into the labor market between 1992 and 2011. First, we use detailed administrative records from the California Community Colleges Chancellor's Office (CCCCO), which include college-level and student-level information. Specifically, we employ information on students' demographic background, course-taking behavior, and degree receipt by term. ${ }^{5}$ We match these data to quarterly student earnings

\footnotetext{
${ }^{5}$ Only three colleges use the quarter system, which makes synchronizing the school year to the calendar year straightforward. For the rest, which are on the semester system, we categorize the spring semester (January to June) as the first and second quarters, with summer term and fall semester as the third and fourth quarters, respectively.
} 
information from the state's unemployment insurance (UI) system. ${ }^{6}$ These data are linked to student information by the CCCCO and extend from 1992 to 2012. Approximately 93 percent of students in our college data are matched to earnings records. ${ }^{7}$ Prior to 2001 there were several changes in reporting practices and retirements within the college system and so we focus on the college data from the later half of the period it is available.

The CCCCO data contain a vast amount of student-level information. Demographics, such as a student's age, race, and gender, are recorded in each academic term for which a student was enrolled in a course. We define enrollment based on the units attempted in a given term: part-time between six and 12 units, and full-time as more than 12 units. These two definitions are consistent with the number of units needed to qualify for different levels of financial aid. We do not differentiate between students taking fewer than six units and those not enrolled because the workload of a single course is not likely to depress earnings. ${ }^{8}$

We categorize the content of different courses and programs according to the Taxonomy of Programs (TOP), a system unique to California's community colleges but similar to the more commonly used Classification of Instructional Programs (CIP) codes. All community colleges in the state are required to use the TOP, which grants us a uniform categorization of the topical content of degrees and courses across time that is common across all of California's community colleges. In particular, the CCCCO identifies some TOP codes as CTE, which allows us to note students who take such courses and earn CTE-identified degrees. In this analysis we focus on

\footnotetext{
${ }^{6}$ We have access to these data as they are provided to the CCCCO through the California Employment Development Department (part of the California Department of Finance).

${ }^{7}$ Students may not be observed in the earnings records for several reasons including being in an uncovered sector (including armed forces members, railroad workers, self-employed, domestic workers and unpaid family workers) over the period, a true lack of any formal earnings, or having moved out of the state with no recorded earnings in California. See http://www.labormarketinfo.edd.ca.gov/data/QCEW_About the Data.html for details of quarterly earnings coverage.

${ }^{8}$ In the appendix, we show that adding a separate control for being enrolled for less than six units has no effect on earnings or on our estimated returns.
} 
awards in TOP codes designated as CTE programs. The narrowest TOP code is a six-digit number denoting a field. The first two digits identify one of 24 broad disciplines, such as education, biological sciences, or health. There are CTE and non-CTE fields within each discipline, though the distribution is not uniform across disciplines; for example, engineering and industrial technologies (TOP code 09) has many more CTE fields than the social sciences (TOP code 22).

We evaluate the effects of CTE award attainment by looking at four categories representing a traditional sub-baccalaureate degree (associate degree) and several other shortterm certificates. Specifically, we categorize award holders into four categories: Associate of Arts/Sciences degrees (typically 60 credit hours); 30-59 credit certificates; 18-29 credit certificates, and 6-17 credit certificates. ${ }^{9}$ Students enrolled full-time typically take 15 units per semester, so these various awards range from two years of full-time coursework to less than a semester.

\section{Sample Construction}

To evaluate the returns to CTE awards, we first construct a sample of students who earned a CTE certificate or degree between 2003 and 2007. While our college-based data do extend back into the $1990 \mathrm{~s}$, there were a number of changes in reporting requirements for individual colleges during that period. This allows us to focus on a period with consistent data reporting and quality, and primarily use the community college data from 2001 forward. ${ }^{10} \mathrm{We}$ begin with relatively broad categories of TOP code disciplines. We focus on the eleven largest

\footnotetext{
9 The data do not allow us to disaggregate beyond these groupings.

${ }^{10}$ We use 2003 as the first year of student completions in order to have pre-enrollment data for all students.
} 
TOP code disciplines to maintain reasonable sample sizes for our discipline-specific estimates. Combined, these disciplines cover approximately 98 percent of all CTE degrees granted during the period. We conduct the analyses separately by discipline. Focusing on these large disciplines allows us to look separately at degrees within specific disciplines.

We limit the sample of treated individuals to just those students who earned a CTE degree - though this may not have been their highest degree. We place no restrictions on the first term of enrollment, which means some of these students may have earned their degree in just a year while others may have taken much longer. On average students take four years to complete their first CTE award. We match earnings data back to 1992, regardless of when students began their coursework. For most students, the earnings data extend from before they enrolled for the first time in a community college course until after they graduated. We limit the sample to years of data between five years prior and ten years after a student's first term enrolled in a community college. We drop earnings and academic data for students in the years before they turned 18 years old. Students may take classes at multiple colleges throughout their academic careers and they can also transfer credits from one community college to another. For the purposes of our sample and because of certain data limitations, we consider each student at each college as an individual case. ${ }^{11}$

While transfers to four-year universities are common among community college students generally, they are far less common among CTE students. To avoid conflating the value of a four-year degree with the value of completing shorter CTE programs, we drop from our sample any individuals that our data indicate transferred to a four-year college. We examine sensitivity

\footnotetext{
${ }^{11}$ A student who earned a degree at college $\mathrm{X}$ and a degree at college $\mathrm{Y}$ will be included in our data twice, once for his career at each college. For a student who took courses at college $\mathrm{X}$ and college $\mathrm{Y}$, but only earned a degree at college $\mathrm{Y}$, we only observe the coursework and degree earned at college $\mathrm{Y}$; the coursework at college $\mathrm{X}$ drops out of our sample.
} 
to this choice following our main results and show that, for most CTE fields, this does not alter our conclusions.

\section{Statistical Framework for Estimating Returns to CTE Programs}

Our goal in this paper is to estimate credible causal effects of CTE programs on earnings, both overall and by individual CTE disciplines. An answer to the fundamental question of whether CTE programs produce returns comparable to traditional academic, four-year degrees is essential in a policy environment that recommends CTE degrees as an important alternative to traditional baccalaureate degrees. An advantage of studying CTE programs is the fact that most CTE students do not enroll directly from high school, unlike traditional college students, and so we can use standard identification approaches that make use of earnings prior to enrollment to control for unobserved characteristics.

Our goal is to identify the earnings effect of completing a CTE degree relative to not completing such a degree, or

(1) $\mathrm{E}\left(\mathrm{Y}_{\mathrm{it}} \mid \mathrm{CTE}\right.$ Award=1) - E(Y $\mathrm{Y}_{\mathrm{it}} \mid \mathrm{CTE}$ Award=0),

where $Y_{\text {it }}$ represents quarterly earnings. The key challenge, as in much of the literature on returns to education, training programs, or costs of worker displacement, is that we cannot observe the same individual in both states of the world, with and without the CTE award, at the same time. Prior literature has used a variety of approaches to measure earnings in the absence of an award, including those never enrolling in a program, those not completing a program, or those completing different programs. Here we use fixed effects approaches in which earlier earnings of individuals who eventually receive awards, adjusted for growth and economy-wide factors over time, serve as a proxy for later earnings in the absence of the award. We include control groups 
in order to assist with the identification of time and year dummies and improve efficiency. ${ }^{12} \mathrm{We}$ show below that our results are not sensitive to changes in our control group, reflecting the fact that the thrust of our identification strategy comes from individual degree recipients' own prior earnings.

Given the focus on returns to degrees in the broader literature on higher education, we view it as important to estimate returns to comparable, structured courses of study in the CTE arena. CTE certificate and degree programs represent a focal course of study, similar to traditional academic degrees, that are meant to prepare students for a particular occupation or set of occupations. Moreover, although there are many other potential questions of interest, such as whether there is a return to accumulating credits (but not necessarily a formal degree or certificate), or how returns to CTE degrees vary across colleges, these are secondary to the question of whether there is an average return to the degree or certificate itself. Issues of selection into specific fields are also of substantial interest, but again are secondary to establishing credible returns across those fields. Thus, our parameter of interest is receipt of a CTE degree or certificate.

To answer the question of whether completion of CTE programs improves the earnings of award receipients, we use a regression framework similar in spirit to the literature on nonexperimental evaluations of worker training programs. ${ }^{13}$ The majority of students in our sample of those taking CTE courses have earnings prior to enrollment and many have a substantial earnings history prior to enrollment. We construct our estimation strategy to make use of these

\footnotetext{
${ }^{12}$ See Jacobson, Lalonde, and Sullivan (1993) for a clear discussion of similar models, including the role of the control group (in their case never displaced workers) in the estimation.

${ }^{13}$ See, for example, Heckman, and Smith (1999), or Heckman, Lalonde, and Smith (1999).
} 
pre-enrollment earnings and to better isolate the causal effect of CTE awards on earnings.

Specifically, we estimate equations of the form:

(2) $\ln \left(\right.$ Earnings $_{i t}=\alpha_{i}+\gamma_{t}+\theta_{i} t+\pi$ Enrolled $_{i t}+\beta$ Degre $_{i t}+\sum_{j=18}^{65} \delta_{j} 1(\text { Age }=j)_{i t}+$ $\varepsilon_{i t}$

These regressions include individual fixed effects $\left(\alpha_{i}\right)$, so that the effect of the award receipt is identified from the within-person changes in earnings from before to after the award is received. They also include individual-specific trends, $\theta_{i} t$, to avoid bias in the estimates from unobserved factors that may be correlated with completion and that change at a constant rate over time. This is important since we show below that there is evidence suggesting different preenrollment earnings trends between our treatment and control groups, so that a standard fixed effects approach may not completely eliminate sources of bias. This specification reflects the approach recommended by Dynarski, Jacob and Kreisman (2016) in their recent consideration of whether fixed effects alone are likely to be sufficient to fully control for pre-enrollment earnings patterns.

The specification also includes controls — in the form of dummy variables — for calendar year and age. We enter age as a series of dummy variables $\left(\delta_{\mathrm{j}}\right)$ to capture non-linear age effects on earnings. The coefficient $\pi$ captures the effect of an indicator for periods in which the individual is enrolled at the community college either full- or part-time. This is to avoid conflating part-time or otherwise reduced earnings while enrolled with pre-enrollment earnings as a base against which this specification implicitly compares post-award earnings. The coefficient of interest, $\beta$, takes a value of one in periods after the student has graduated.

This equation could be estimated using only degree recipients with earnings observed both before and after the award receipt. In this approach, the dummy for "Degree" initially 
equals zero, and then turns to one upon completion of the award. By the end of the sample period, every individual in the treated part of our sample has completed the award.

In our main results, we also include control groups in the estimation of equation (2). Our control groups include those taking at least eight units in the particular CTE discipline, but not receiving a degree or certificate. They are constructed on the basis of both data availability and the desire to best identify those individuals most similar to award recipients in particular CTE programs. We have earnings data only for individuals who have had some contact with the California Community College system, but that involvement can be as minimal as enrollment in a single course. Control groups within the fixed effects approach used here serve simply to identify the age and year effects and so better estimate the hypothetical path of earnings in the absence of degree receipt. In Appendix Figure A2, we show the distribution of units completed for both treatment and control groups. Control group members, as expected, complete far fewer units than the treated group. At the same time, treatment and control group students are far more similar in terms of demographic characteristics within disciplines than across, reflecting differences across disciplines in the characteristics of students taking even a few classes (Table 1). As shown below, our estimates are not sensitive to using alternative control groups.

The main concern with non-experimental estimates of the effects of education on earnings is that individuals who choose to enroll and complete degrees may be more motivated or productive than those who take only a few courses or do not enroll at all. This could lead to a systematic overstatement of the earnings effects of these programs. Our inclusion of individual fixed effects and individual-specific trends should address many of these concerns. This approach is feasible in the CTE setting because so many CTE students are involved in the labor 
market prior to their enrollment, and our approach makes good use of this unique feature of CTE programs. $^{14}$

There remain some potential concerns and sources of bias with our specification. Specifically, if transitory, unobserved shocks to our treated group affect both their likelihood of completing a degree and their subsequent earnings (and are not captured by their pre-enrollment earnings levels or growth rates), this could bias our estimated returns. This cannot be completely addressed with the observational data available here, a caveat similar to that made by Jepsen et al. (2014). A recent review by Belfield and Bailey (2017) highlights the challenges of using fixed effects estimators in this setting. Our access to data with both many years of earnings and large numbers of students allows us to overcome many of the challenges they cite, and we show below that our results are robust to a number of specification changes. Overall, the ability to control for pre-enrollment earnings and earnings trends, and the very large samples available from this unique dataset, allow us to provide arguably the most convincing estimates to date of the labor market returns to a wide variety of specific CTE programs. ${ }^{15}$

Given that we have data only on individuals who have at one point enrolled in the community college system, our sample is necessarily conditioned on that enrollment. More specifically, we condition on participation in at least some level of CTE coursework and so our

\footnotetext{
${ }^{14}$ Note that this means we will be identifying off of individuals that do have a pre-enrollment earnings history. If there is heterogeneity in returns to these CTE programs across more- and less-experienced workers, our estimates based on equation (2) will predominantly represent the returns to award recipients with more prior work experience, since those without such experience will not contribute much of the within person variation we need for this identification approach. We investigate this by focusing on returns for workers of different ages and do not find evidence that this systematically changes our estimates.

${ }^{15}$ Recent work in progress by Flaaen, Shapiro, and Sorkin (2016) makes a similar point about the effect of matching or propensity score approaches that control for observables in settings that also include fixed effects. In their work on the earnings costs of displacement (estimated with individual fixed effects), they note that reweighting procedures based on observable characteristics make little difference to their estimates. They explain this by noting that once individual fixed effects are included "reweighting only changes estimates if these characteristics predict different slopes of earnings." In our case, the inclusion of individual-specific earnings trends would similarly address selection factors associated with different earnings slopes.
} 
results are directly applicable to that portion of the population. Similarly, our earnings results reflect the economic environment of California from 2001 to 2011, but we note that this includes a great deal of heterogeneity across both geography and time. For example, county unemployment rates over this time period ranged from nearly 17 percent in Fresno County in 2010 to under six percent in San Francisco during 2004. ${ }^{16}$ Moreover, the California Community College system is the largest community college system in the country, serving one out of every six community college students nationwide. Thus, while some concerns about external validity and sensitivity to market conditions will always be relevant to studies based on a single state or single system of higher education, our sample is broad and diverse along many dimensions. This, along with our ability to control for fixed and smoothly trending unobservables, make our estimates widely applicable.

Finally, for a subset of our sample, we utilize an alternative identification approach, based on access to a very rich set of additional control variables that can proxy for underlying abilities that might be correlated with the propensity to complete a CTE award. As a robustness check, we estimate models that do not include individual fixed effects, but that control for high school math and English language arts test scores and parental education, as well as demographic characteristics. We expect that this approach, which controls for a fuller set of observable characteristics, but cannot control for fixed unobserved characteristics or for trends that are correlated with degree receipt, will lead to higher estimated returns. We also test models that interact estimated returns with pre-enrollment test scores, but find no evidence that those with higher test scores (a proxy for ability) have systematically different returns to completion.

\footnotetext{
${ }^{16}$ See, http://www.labormarketinfo.edd.ca.gov/data/unemployment-and-labor-force.html, for county-level unemployment rates in California from 1990 to the present.
} 


\section{Results}

\section{A. Summary Statistics}

Table 1 provides detailed summary statistics for our CTE award recipients for the eleven largest TOP codes, or CTE disciplines, and the associated comparison groups. Several points from Table 1 inform our interpretation of the results below. First, there is tremendous heterogeneity in student characteristics, distribution of award types, and pre-enrollment labor market attachment across the eleven CTE disciplines. For example, just 36 percent of those receiving awards in the area of business and management were employed just prior to their initial enrollment, but more than half of those in health or public and protective services were employed immediately prior to their initial enrollment. Gender differences across fields are also striking; 94 percent of those receiving awards in engineering and industrial technology were male, but only 12 percent in family and consumer sciences were male. Only one-third of award recipients in health were male. This points out the potential importance of estimating returns to degrees separately across discipline, since observable (and unobservable) characteristics vary dramatically across disciplines and may have important implications for estimating and interpreting overall returns.

The average age at enrollment in our sample ranges from a low of 21 for commercial services to over 30 for agriculture and law, differentiating this sample from more traditional, non-CTE college programs. Between 50 and 70 percent of students had at least one quarter of nonzero earnings before first enrolling, and approximately 40 percent had more than five quarters. Depending upon the field, we observe between five and 15 quarters of nonzero earnings prior to enrollment. 
Table 1 also provides information on how similar our treatment and control groups are to one another. Age and gender distributions are similar across the treatment and control groups within specific TOP codes. This is important given the large differences in these characteristics across TOP codes and suggests the potential value of having control groups that are specific to each discipline. One potentially important difference between the treatment and control groups is that, across TOP codes, the control group is usually more likely to be employed prior to enrollment. This may reflect the greater tendency of employed students to take only a few courses, rather than completing a full degree or certificate program. Our use of individual fixed effects should prevent this from being a major source of bias, by effectively conditioning on preenrollment earnings.

Before turning to regression models, Figure 1 shows event-study graphs of the pattern of log earnings around the time of completion of certificates and degrees. These figures come from regressions of log earnings on a vector of quarterly event-time dummies (from 20 quarters prior to 25 quarters post) defined for the treatment group, along with controls for calendar year, age, and current enrollment. As in the regression models specified above, the control group contributes to estimation of common calendar year, age and enrollment effects. We show these results for each of the four award lengths for all TOP codes together, and for the three largest TOP codes. Focusing on the figures for all TOP codes together, several patterns are obvious. First, there do appear to be noticeable increases in earnings following degree receipt relative to the period prior to completion. Second, there is some visual evidence that for several disciplines and award types the treated group (relative to the comparison group) had negative earnings trends prior to their enrollment and completion of degrees. These event study models, which do not account for individual fixed effects and trends as in the main estimating equation, instead 
serve to highlight the scope of the identification problem when not controlling for fixed effects and trends. This makes it important to test for the presence of non-parallel trends prior to enrollment and to check our estimates' robustness to controlling for such trends. Finally, these event-study graphs hint at the heterogeneity in returns we find across different fields and award lengths. Among associate degree recipients, for example, there appear to be large returns in health, but small or no returns in the area of business and management. In contrast, among the shortest awards, of just six to 17 units, public and protective services seems to show larger earnings increases after completion than health or business and management.

\section{B. Regression Results}

\section{Main results}

We next turn to regression results, using the specification summarized in equation (2). Recall that our control group for each TOP code consists of students who earned at least eight units in that discipline within their first three years of enrollment at the college, following the CCCCO's definition of a CTE-degree bound student.

In Table 2, we present results from our preferred regression specification by certificate or degree length and discipline. Disciplines are listed from the largest in terms of awards granted (at the top) to the smallest (at the bottom). First, we note that there are positive and significant returns to most of the CTE programs studied here. Table 2 shows that, in 34 out of 44 cases, there are positive and statistically significant earnings effects of these CTE certificate and degree programs. For the relatively large programs, effects are estimated quite precisely so that even some modest returns are statistically significant. For example, short certificates of under 18 units in information technology show one of the smaller returns at approximately 10 percent, and these 
returns are statistically different from zero. ${ }^{17} \mathrm{~A}$ second broad finding from Table 2 is that there is a striking degree of heterogeneity in estimated returns across different TOP codes. A 30-59 unit certificate in business, for example, produces an earnings effect of approximately 11.5 percent (coefficient 0.109), compared to an estimated return of 17 percent (coefficient of 0.154 ) in public and protective services, and nearly 49 percent in health (coefficient of 0.398 ).

Table 2 also shows substantial heterogeneity by program length, not always in the expected direction. In many cases, returns do increase as the length of the program increases, but there is not perfect monotonicity. For example, in health, estimated returns increase as the length of the certificate program grows. In contrast, in public and protective services, the estimated return to certificates requiring 18 to 29 units exceeds the returns for longer certificate programs and the AA/AS degree. To some extent, this lack of monotonicity may reflect that many of the broad TOP codes are themselves heterogeneous in terms of the types of CTE programs they include. Public and protective services, for example, includes programs in fire protection, administration of justice, and policing. This means that differences in program length may be confounded with differences in the nature of the training and related occupations. Below, we aggregate programs of different lengths and show that, on average, certificates with greater unit requirements have higher returns, even though this may not be true within every individual TOP code.

A different type of heterogeneity in returns to community college degrees is highlighted in recent work by Andrews, Li, and Lovenheim (2016) who estimate quantile treatment effects and show substantial variation in earnings of community college graduates. While their results do not include shorter-term certificates, the heterogeneity in returns we show here across CTE

\footnotetext{
${ }^{17}$ In the log earnings specification, the percentage effect on earnings is given by $\mathrm{e}^{\beta}-1$, where $\beta$ is the reported coefficient.
} 
fields is consistent with the broad range of earnings effects for community college students shown in that work.

Several recent studies have estimated similar models using earnings levels, rather than the log specification used here. Appendix Table A2 shows results from repeating our basic specification on the same sample, but using earnings levels as the dependent variable. Results based on earnings levels produce similar results, though with implied percentage effects (using pre-enrollment earnings as a baseline) that are typically smaller than results in Table 2. Appendix Table A3 shows estimates of similar models with the outcome being the probability of employment (having positive earnings). Those results show small positive effects on employment in most fields, with estimated effects typically between two and four percent. The columns of Table A2 where we estimate the main results in earnings levels are consistent with this finding. When we include zero earnings observations (not shown) our estimated effects on earnings increase slightly, reflecting this additional effect of improving the chances of having positive earnings. In general, the results using levels are similar to the log specifications in terms of which fields have large, or very large returns. The very right-skewed distribution of quarterly earnings leads us to prefer the log specification, which should be less sensitive to some extreme values for earnings.

Summary statistics from Table 1 indicate large gender differences in enrollment patterns across specific programs and disciplines. Because we also document substantial heterogeneity in returns across disciplines, we next investigate the returns to CTE programs separately for men and women. Table 3 shows similar returns for men and women in most disciplines. Information technology is one exception, with certificates of 30 to 59 units showing large, marginally significant returns for women and low or no returns for men. The reverse is true for AA/AS 
degrees in the Information Technology area. Relatively few women receive certificates and degrees in the information technology TOP code and so these results for women are imprecisely estimated. Among all associate degrees awarded to women, fewer than two percent are in this TOP code. This also raises the possibility of some gender-specific selection into fields that could complicate interpretation of returns. Our summary from these results overall is that, although there are some differences in returns by gender, they are small relative to gender differences in selection into CTE fields.

To better understand this variation in returns and field choices, we have also estimated returns separately by more detailed, four-digit TOP codes, which correspond much more closely to well-defined fields of study or occupations. For example, rather than estimating the return to all 18 to 29 unit certificates in the broad field of family and consumer sciences, we instead allow separate coefficients for returns to programs in: child development/early care and education; fashion; and interior design. These results are displayed in Figure 2, in which our estimated returns by four-digit TOP code and program length are illustrated on the vertical axis, grouped into the broad disciplines and program lengths we used in Table 2 . The advantage of this is that it allows us to show variation in returns across the specific programs in which students enroll. For each discipline we also show (filled in circles) the overall return for the discipline and degree length for comparison. Figure 2 displays the statistically significant returns for 200 different programs. For ease of display, we omit 11 coefficients over 1.0 and 7 coefficients under -0.3 ; another 195 coefficients were not statistically different from zero. A similar figure with all estimated returns, including those not statistically different from zero, is shown in the Appendix. ${ }^{18}$ There is substantial variation in returns to specific four-digit TOP codes around the

\footnotetext{
${ }^{18}$ The full list of individual estimates at the four-digit TOP code level is available online at http://jhr.uwpress.org/.
} 
average for the broad discipline. For example, in health the estimated coefficients range from essentially zero for a small certificate in emergency medical services to approximately 0.20 for a 30-59 unit certificate in health information technology, to a high of 0.83 for an associate degree in respiratory care therapy.

This variation in returns - across and within disciplines - has an obvious counterpart in the literature on variation in returns to college by major. Altonji, Bloom, and Meghir (2012) report returns - based on OLS estimation with detailed occupational controls—-for 23 different college majors. They show that the standard deviation of returns across these majors ranges from 0.07 for women to 0.10 for men. Our results are similar, with a standard deviation in estimated returns across the two-digit TOP codes of 0.08 to 0.17 , depending on the length of the certificate or degree. The literature on college majors has often struggled for convincing identification of the true returns to college majors; the results reported by Altonji, et al. (2012) likely include some bias from unobservables that could contribute to the variation across majors. Our results for CTE programs are among the few that are based on estimation that controls for time-invariant unobservables.

Work by Arcidiacono (2004) looks at variation in returns across just four broad four-year college majors and finds a span of 10 to 20 percentage points, after controlling for unobserved heterogeneity in selection into majors, a similar span to our results if we exclude associate's degrees in health. Overall, our results demonstrate that, even after controlling for potential ability differences (via the fixed effects and individual-specific trends), there is variation across CTE fields that is roughly comparable to the extent of variation in returns across majors found for bachelor's degrees. 
The heterogeneity across specific types of CTE programs may explain why studies that consider all CTE programs can be challenging to interpret. Differences in the mix of degree programs offered, or specific patterns of enrollment, may alter the overall estimate of returns. At the same time it is of interest to present a tractable summary of expected returns for the population of CTE students. One way to summarize these estimated returns is to calculate a weighted average return where the weights take account of the relative frequency of degrees in specific disciplines. This also allows for a way to summarize overall returns that captures differences in enrollment patterns by gender. In Table 4, we provide this summary by calculating weighted averages across TOP codes for each degree type.

The weights for this exercise are the fraction of all degrees of a specific type earned in the four-digit TOP code out of all such degrees earned. ${ }^{19}$ This provides an estimate of the typical return for a random student receiving a CTE associate degree or certificate of a given length, with TOP codes that grant relatively large numbers of degrees receiving greater weight. Given the very large returns to health-related occupations, we also repeat the exercise for all disciplines other than health. This shows smaller overall returns for women than for men, particularly when health is excluded from the estimates. Given the similarity across gender of discipline-specific returns in Table 3, these results largely reflect differences in the specific programs completed by men and women. For women, the returns range from approximately ten percent for certificates requiring just six to 18 units to approximately 40 percent for the associate degree. For men, the comparable range is 14 to 45 percent.

\footnotetext{
${ }^{19}$ This is not the only sensible way to aggregate returns across disciplines. This approach produces an overall return to the "average" degree recipient. Another strategy might be to weight by the number of students attempting degrees in this field; this would produce an average return more appropriate to a typical potential awardee.
} 
In the lower panel of Table 4 we repeat this summary of results excluding health programs. This shows smaller, but still substantial, positive average returns for CTE programs of all lengths outside the health sector. Overall, estimated returns outside of health range from nine to 20 percent among women, with the largest average returns accruing to certificates requiring 30 to 59 units of study. Among men, average returns range from 14 to 26 percent, depending upon the length of the certificate or degree. For comparison, Jepsen et al. (2014) report earnings returns for CTE associate degrees (excluding health) of approximately $\$ 1,300$ to $\$ 1,500$ in quarterly earnings, or increases of 26 to 30 percent given their baseline quarterly earnings of approximately $\$ 5,000$. Our results are in a similar range.

These results provide strong evidence of the potential of short-term CTE programs to substantially raise earnings. Even excluding health-related occupational programs, which are known to have substantial returns, our findings show the potential for significantly improved earnings for students who complete these short-term CTE programs.

\section{Robustness Checks}

\section{a. Robustness to individual-specific trends}

Our main specification allows for individual-specific trends, an approach that has been recommended in this literature (Jacobson, Lalonde and Sullivan, 2005; Dynarski, Jacob and Kreisman, 2016), but that has not always been implemented. While including individual-specific trends can potentially address concerns about bias that remains in a fixed effects setting, it can also raise other concerns and may not effectively address bias in the presence of dynamic treatment effects. In this section, we examine the performance and robustness of models that control for individual-specific trends. 
To test whether individual-specific trends in earnings are correlated with degree and certificate completion, we follow the suggestion in Dynarski, Jacobs, and Kreisman (2016) who recommend testing for earnings trends that are correlated with completion by estimating regressions of pre-enrollment earnings (for treatment and control groups) that include indicators for eventual completion interacted with a time trend. We regress log earnings prior to enrollment on trends, and on trends interacted with a dummy equal to one for those individuals who eventually complete a degree or certificate. Additional controls include year and quarter fixed effects, and, in some specifications, demographic controls. When we group all TOP codes together, our results indicate that the parallel trends assumption is violated for only one of the four award lengths (certificates of 18 to 29 units). When we disaggregate by TOP code, however, we find that five of the 40 coefficients that could indicate differential pre-enrollment trends are statistically different from zero. While evidence of potential bias occurs in a minority of the estimates, it is more than can be clearly ascribed to chance. This, along with the visual evidence of pre-enrollment trends shown in Figure 1 supports a primary specification using individualspecific trends.

Unfortunately, models that include controls for individual-specific or group-specific trends can conflate the influence of pre-treatment trends with trends or dynamics in the treatment effects (Wolfers, 2006), and as a result may not effectively correct estimates for pre-treatment trends. One of the implications of the Wolfers (2006) argument is that individual-specific trends should only be used if there is an a priori reason to believe they may be important. In our case, a primary concern with estimating returns to education in a non-experimental framework is that unobserved productive ability or skill might influence both earnings (levels and trends) and completion probabilities, and so we view it as important to test for this possibility in our setting. 
To consider whether the critique of Wolfers (2006) with respect to including individualspecific trends might be applicable in our analysis, we combine the testing for differential trends described above with tests for whether including individual-specific trends significantly alters our estimated returns to completion, and a careful examination of the direction of any resulting changes. Seven of the 44 coefficients from Table 2 are significantly changed (using a generous ten percent significance level) when we drop the individual-specific trends.

To understand these two sets of test results, we combine them in Table 5, which shows results of tests for differential pre-enrollment trends (column one) and for equality of our key coefficients with and without controls for individual-specific trends (columns two through four). Note that Table 5 does not include all TOP codes, but rather only those six TOP codes for which there were either statistically significant differential pre-earnings trends for award recipients or evidence suggesting rejection of equality of coefficients with and without individual-specific trends. (The remaining TOP codes did not meet these conditions.)

Among the five awards for which there were significantly different pre-enrollment trends, as indicated by stars in column 1, one award produces results in which the trends specification moves the coefficients of interest in a direction consistent with the sign of the pre-enrollment trends. The remaining four cases produce results in which including trends does not significantly alter the key coefficient, and are split with two cases moving point estimates in the expected direction and two not.

Among awards in the health TOP code, there is evidence that eventual award recipients have more negative earnings trends prior to enrollment. Table 5 also shows that conditioning on individual-specific trends leads to larger estimated returns, consistent with a reduction in bias 
from controlling for more negative pre-enrollment trends among those who eventually complete awards.

In contrast, within public and protective services, we find evidence that controlling for individual-specific trends may not control well for potential bias. Table 5 shows that including trends does not move the estimates in the expected direction. Here, our testing provides evidence that pre-enrollment trends for certificates of 30 to 59 units are significantly more negative among eventual award completers. We would thus expect that controlling for individual-specific trends should produce larger estimated returns; but we find the opposite, with the coefficient falling from 0.19 to 0.15 in the trends specification, although this difference is not statistically significant. Given that the only statistically significant changes in coefficients move in the expected direction (for health awards) we prefer the specification that includes trends, but confirm Wolfers' (2006) note of caution concerning this specification.

We have also considered the possibility of dynamic treatment effects, which may confound the pre-enrollment trends, by allowing the effect of award completion to vary with time since the degree was granted. These results, summarized in Appendix Table A1, show fairly stable treatment effects over time for many awards and do not substantially change our conclusions regarding the specifications with and without individual-specific trends. There is evidence that returns to awards in some TOP codes grow with time since the award, but relatively little evidence of returns shrinking substantially over time.

\section{b. Comparisons with OLS and detailed observable controls}

An alternative to the fixed effects approach that is the basis for our estimates is a crosssectional, OLS, approach that includes detailed controls for observable heterogeneity in ability or 
preparation. Even if this does not solve all of the omitted variables concerns, the frequency with which such approaches have appeared in this literature make it useful to compare with our main results. Importantly, for a subset of our data (certain entry cohorts), we have access to test scores from students' high school years, and to their parents' completed levels of education, observable indicators that are likely to be powerful predictors of future academic success. These results are summarized in Table 6. We estimate OLS models for earnings, including the additional controls for test scores and parental income, as well as fixed effects models, for the individual TOP codes shown throughout. We then summarize the resulting coefficients using the same weighted average approach shown in Table 4.

As expected, most of the estimated returns based on the fixed effects specification are smaller than the OLS estimates with controls for test scores and parental education. In most cases, however, these differences are relatively small, often within a standard error of the fixed effects estimate. Given the much smaller samples sizes available for this exercise, we do not draw strong conclusions here. We note that this is consistent with a role for unobserved fixed characteristics and trends, and confirms the strong evidence that CTE programs significantly increase earnings, even when returns are estimated in a rigorous way that controls for unobservable factors that are either time-invariant or trend smoothly over time. Recent work by Andrews, Li, and Lovenheim (2016) uses a similar approach, based on OLS regression with very detailed controls. We have similar controls for family background, and pre-college ability in the results in Table 6. Our results suggest that detailed individual observables may leave room for bias from unobservables that are well-addressed, when feasible, with longitudinal data methods.

c. Robustness checks on main fixed effects and individual trends approach 
We have also estimated our main specification using two alternative samples. For convenience, column 1 of Appendix Tables A4 through A7 repeat our main specification. Our reliance on panel data (fixed effects) methods raises a concern that we are identifying effects that will be relevant only to older workers with substantial earnings histories. To help gauge the likely magnitude of this concern, in the second column of these tables we show results for those over age 30 at first enrollment. In most cases, our results for the full sample and the sample of those age 30 and over at time of enrollment are similar. Thus, there is little evidence here to suggest that our main estimates are less relevant for younger CTE students.

A second robustness check examines our initial choice to eliminate students who eventually transfer to a four year institution. In work focusing specifically on CTE degree and certificate programs, the role of transfers in driving returns is ambiguous. On the one hand, students focused on these CTE awards may be less inclined to transfer, and so there may be less concern that the CTE awards are associated with higher earnings partially because they facilitate additional degrees or college attendance. This should mean that eliminating students who transfer would reduce our estimated returns. On the other hand, transfers could work in a very different way if academic and CTE tracks are viewed as substitutes for one another. Suppose that individuals take a few CTE courses and thus qualify as a member of our control group; if many of these students then decide instead to pursue a transfer path, the earnings of our controls may benefit disproportionately from their decisions to transfer to four-year colleges. In some sense, receiving a CTE degree could signal that a student has not opted for a four-year degree. This is related to the "diversion" effect of community colleges in which attendance diverts students from a four-year degree (see Belfield and Bailey, 2011 for a review and discussion). For CTE programs, there may be an additional issue of diverting students from non-CTE programs that 
are intended to lead to transfers. If this story is important for our CTE students, we might expect that eliminating students who successfully transfer would disproportionately eliminate high earning control-group members and thus increase our estimated returns.

In column 3 of Appendix Tables A4-A7, we add to the overall sample those students who transfer. Depending on the discipline, between 12 and 40 percent of CTE students transfer to a four-year college. These results including students who eventually transfer are very similar to those shown in column 1, suggesting that transfers do not play a major or systematic role in generating the returns estimated here. One exception to this pattern is for associate degrees in Business/Management. Including those who transfer produces smaller returns to associate degrees in Business (as well as a few other fields to a lesser degree). Business programs may be a particularly heterogeneous group on this dimension, since many four-year colleges offer business degrees, but they are also listed as part of the CTE offerings within the California community colleges we study. There are both transfer-focused paths within business and specific two-year CTE degrees that do not lend themselves to transfers. These results suggest that focusing on those students who do not transfer provides a better estimate of the effects of the CTE programs aimed at producing shorter-term awards.

We have also estimated models that test our decision to control only for enrollment of more than six academic units. In Column 4, when we add a control for enrollment in one to five units into the log wage equation, there is virtually no change in our estimates.

In the final columns of Tables A4-A7, we show how varying our control group definition affects the estimated returns. In the final columns we show that results are not sensitive to restricting our control group to be from approximately the same cohorts as the treated group (first enrolling in years 2001 through 2005). We have also estimated models with a single control 
group, consisting of students taking eight units of any CTE field, and models with no control group. Neither of these extreme changes to the controls groups alters our estimates in a systematic way, reflecting that individuals' own pre-enrollment earnings supply the key component of our identification approach.

Finally, while not shown in the tables, we conduct one other exercise to test to the stability and robustness of our main results. This exercise is motivated by the possibility of heterogeneous returns to CTE programs. As discussed earlier, a potentially important limitation on the generalizability of our results is that we only observe the effect of these CTE awards for the population that successfully complete them. If returns are systematically higher for those with particular observed or unobserved characteristics (including those actually completing), these results may not represent the true return for a randomly selected student. To partially address this concern, we have also estimated models that allow for an interaction between the effect of completion and the test scores used for the analysis in Table 6. If these test scores provide a proxy for ability, it is important to know whether higher ability students also show higher returns to degree receipt. All interactions between test scores and degree receipt are small and statistically insignificant, providing little evidence that returns differ systematically across students of different academic abilities.

\section{Discussion and Conclusion}

Career technical training has been touted by many as one of the few concrete pathways to improved earnings for those without a four-year college degree (Hoffman and Reindl, 2011; Bosworth, 2010; Holzer \& Nightingale, 2009; Harmon and MacAllum, 2003). The effectiveness of these programs in raising earnings, however, has not been convincingly established. For-profit 
competitors in the CTE space are frequent targets of negative press; the few evaluations we have of CTE within public-sector community colleges have produced mixed results and have frequently been hampered by methodological shortcoming and small samples. The potential of CTE to improve labor market outcomes is highlighted in recent state reform efforts to strengthen CTE offerings in California, and in recent federal funding initiatives directed at CTE and community colleges. Research on the CTE mission of community colleges, the diverse needs of their students, and on the relationship between CTE program offerings and the labor market has been scarce (Rosenbaum, 2001; Grubb, 1996).

The approach used here suggests quite substantial, and generally statistically significant, returns to a wide variety of CTE certificates and degrees offered in California community colleges. By controlling for both individual fixed effects and individual-specific trends, we address many concerns about using observational data to estimate returns to higher education. Our results suggest average returns of up to 45 percent for associate degrees to approximately 14 percent for shorter-term certificates. Health programs, as expected, produce very large returns, but other fields also result in substantial earnings gains. Excluding health leads to returns to the associate degree and certificates of between 15 and 23 percent. While we do not perform a costbenefit analysis, California Community Colleges charge tuition of less than $\$ 600$ per semester for full-time study, and offer many low-income students waivers of these fees, strongly suggesting positive net returns for students who complete awards. ${ }^{20}$

For the purpose of improving human capital development of less skilled workers, these results raise several important points. While the returns estimated here are generally positive and substantial, that does not mean that CTE programs are necessarily an easy solution for all

\footnotetext{
${ }^{20}$ For information on the tuition waiver program and fee information for the system, see http://web.peralta.edu/financial-aid/sample-page/bog/, for example.
} 
students or all workers. First, there is substantial heterogeneity in returns to different CTE programs. Echoing the literature on college majors, the returns to awards with the same number of credit hours vary enormously. While some health fields have very high returns for relatively short programs, other certificate programs offer returns that are mere fractions of those high returns. Even within broad disciplines (two-digit TOP codes) there is substantial variation across specific programs. Second, there is substantial heterogeneity in the observed (and likely unobserved) characteristics of students across disciplines and programs. Thus, sensible policies cannot simply funnel workers into "high-return" programs, since underlying differences in the types of students who enroll in them could be quite important. In particular, the question of how students choose their courses of study and how redirecting students to other fields can alter their returns remain underexplored areas.

Third, understanding the interactions between individuals, programs, and returns, in order to provide concise information to potential students and college administrators, should be a top priority of workforce development policies. Students should be made aware of the likely returns on investments they are making (Klor de Alva and Schneider, 2013). College leaders should, similarly, be aware of which programs and associated investments offer students the greatest return on earnings. Calls to provide better information on labor market returns have begun to be common in the broader realm of education policy, but in the CTE area, given the direct connection to labor market outcomes, this information is especially critical.

Finding effective paths to human capital development for individuals who are unlikely to complete standard four-year academic programs is vital. In California and the nation, declining real wages and record high unemployment for those without college degrees, combined with cuts to many state programs serving these populations, make it essential to understand what programs 
can be most effective. A large literature in economics has considered the most appropriate methods for evaluating worker-training programs, and we draw on the lessons from that literature in this analysis. ${ }^{21}$ Short of a randomized assignment of workers into CTE courses or programs, our approach — combining longitudinal data with a control group — provides the most common approach in the recent literature. ${ }^{22}$ While these results cannot be generalized to every community college system or every CTE learning environment, they do provide the first detailed evidence for a broad group of CTE students that many programs produce substantial earnings gains. Our results show that, even after accounting for individual pre-enrollment earnings levels and trends, and patterns of economy-wide earnings growth, CTE programs raise earnings for students who complete them.

\footnotetext{
${ }^{21}$ See Card, Luve, \& Weber (2010) or Lalonde (1986) for a review and meta-analysis of the job training evaluation literature, respectively.

${ }^{22}$ Card, Luve, and Weber (2010) report that more than half of the qualifying evaluation studies included in their meta-analysis, published since 1990, used longitudinal data with a comparison group.
} 


\section{References}

Altonji, J.G., Blom, E. \& Meghir, C. (2012). "Heterogeneity in Human Capital Investments: High School Curriculum, College Major, and Careers," Annual Review of Economics, Annual Reviews, vol. 4(1), pages 185-223, 07.

Andrews, R.J., Li, J. and Lovenheim, M.F., 2016. Quantile Treatment Effects of College Quality on Earnings. Journal of Human Resources, 51(1), pp.200-238.

Arcidiacono, P., 2004. Ability sorting and the returns to college major. Journal of Econometrics, 121(1), pp.343-375.

Bahr, P. R. (2016). The labor market return in earnings to community college credits and credentials in California (Working Paper). Ann Arbor, MI: University of Michigan, Center for the Study of Higher and Postsecondary Education.

Bahr, P.R., Dynarski, S., Jacob, B., et al. (2015). Labor market returns to community college awards: Evidence from Michigan. (A CAPSEE Working Paper). New York, NY: Center for Analysis of Postsecondary Education and Employment.

Bailey, T., Kienzl, G. S., \& Marcotte, D. (2004a). Who benefits from postsecondary occupational education? Findings from the 1980s and 1990s (CCRC Brief No. 23). Retrieved from Community College Research Center website: http://ccrc.tc.columbia.edu/publications/return-to-sub-baccalaureate-education.html

Bailey, T., Kienzl, G., \& Marcotte, D. (2004b). The return to a sub-baccalaureate education: The effects of schooling, credentials, and program of study on economic outcomes. New York, NY: Columbia University, Teachers College, Community College Research Center.

Bettinger, E. \& Soliz, A. (2016). Returns to Vocational Credentials: Evidence from Ohio's Community and Technical Colleges. A CAPSEE Working Paper. New York, NY: Center for Analysis of Postsecondary Education and Employment. Available at: www.capseecenter.org

Belfield, C. R., \& Bailey, T. (2011). The benefits of attending community college: A review of the evidence. Community College Review, 39, 46-68.

Belfield, C. R., \& Bailey, T. (2017). Model Specifications for Estimating Labor Market Returns to Associate Degrees: How Robust Are Fixed Effects Estimates? A CAPSEE Working Paper. New York, NY: Center for Analysis of Postsecondary Education and Employment. Available at: www.capseecenter.org

Belfield, C., Liu, Y., \& Trimble, M. J. (2015). The medium-term labor-market returns to community college awards: Evidence from North Carolina. A CAPSEE Working Paper. New York, NY: Center for Analysis of Postsecondary Education and Employment. Available at: www.capseecenter.org

Bosworth, B. (2010). Certificates count: An analysis of sub-baccalaureate certificates. Retrieved from Complete College America website: http://www.completecollege.org/resources_and_reports/

Card, D., Luve, J., \& Weber, A. (2010). Active labour market policy evaluations: A metaanalysis. Economic Journal, 120(548), F452-F477. 
Dadgar, M., \& Trimble, M. J. (2016). Labor market returns to sub-baccalaureate credentials: How much does a community college degree or certificate pay? Education Evaluation and Policy Analysis. 37(4): 399-418

Dynarksi, S., Jacob, B. and Kreisman, D. (2016). The Fixed-Effects model in Returns to Schooling and Its Application to Community Colleges: A Methodological note. Working Paper, Center for Analysis of Postsecondary Education and Employment.

Flaaen, A., Shapiro, M, and Sorkin, I. (2016). Reconsidering the Consequences of Worker Displacements: Firm versus Worker Perspective. Working Paper. http://www.aaronflaaen.com/uploads/3/1/2/4/31243277/measuringworkerdisplacements.p $\underline{\mathrm{df}}$

Grubb, W. N. (1996b). Working in the middle: Strengthening education and training for the midskilled labor force. San Francisco, CA: Jossey-Bass.

Harmon, R., \& MacAllum, K. (2003). Documented characteristics of labor market-responsive community colleges and a review of supporting literature. Washington DC: U.S. Department of Education, Office of Vocational and Adult Education.

Heckman, J., Lalonde, R., \& Smith, J. (1999). The economics and econometrics of active labor market programs. In O. Ashenfelter \& D. Card (Eds.), Handbook of labor economics: Volume 3a (pp. 1865-2085). New York, NY: Elsevier

Heckman J., \& Smith, J., (1999). The pre-programme earnings dip and the determinants of participation in a social programme: Implications for simple programme evaluation strategies. Economic Journal, 109(457), 313-348.

Hoffman, L., \& Reindl, T. (2011). Improving postsecondary attainment among adults. Washington, DC: National Governors Association.

Holzer, H. J., \& Nightingale, D. S. (2009). Strong students, strong workers: Models for student success through workforce development and community college partnerships. Washington, DC: Center for American Progress.

Jacobson, L., LaLonde, R. J., \& Sullivan, D. (2005). The impact of community college retraining on older displaced workers: Should we teach old dogs new tricks? Industrial and Labor Relations Review, 58(3), 398-415.

Jepsen, C., Troske, K., \& Coomes, P. (2014). The labor-market returns to community college degrees, diplomas, and certificates. Journal of Labor Economics, 32(1), 95-121.

Kane, T., \& Rouse, C. (1995) Labor market returns to two- and four-year college. American Economic Review, 85(3), 600.

Klor de Alva, J., \& Schneider, M. (2013). What's the value of an associate's degree? The return on investment for graduates and taxpayers. Washington, DC: Nexus Research and Policy Center and American Institutes for Research.

Lalonde, R. (1986). Evaluating the econometric evaluations of training programs with experimental data. American Economic Review, 76(4), 604-620.

Leigh, D. E., \& Gill, A. M. (1997). Labor market returns to community colleges: Evidence for returning adults. Journal of Human Resources, 32(2), 334-353. 
National Center for Education Statistics. Status and Trends in the Education of Racial and Ethnic Groups 2016 (NCES 2016-007). U.S. Department of Education, Washington, DC.

Rosenbaum, J. E. (2001). Beyond college for all: Career paths for the forgotten half. New York, NY: Russell Sage Foundation.

Rosenbaum, J. E., \& Rosenbaum, J. (2013). Beyond BA blinders: Lessons from occupational colleges and certificate programs for nontraditional students. Journal of Economic Perspectives, 27(2), 153-172.

Scott, J., \& Perry, P. (2011). Focus on results: Accountability reporting for the California Community Colleges (A Report to the Legislature). Retrieved from http://californiacommunitycolleges.cccco.edu/Portals/0/reportsTB/March_ARCC 2011.p $\underline{\mathrm{df}}$

Sengupta, R., \& Jepsen, C. (2006). California's community college students (California Counts: Population Trends and Profiles, Vol. 8, No. 2). San Francisco, CA: Public Policy Institute of California.

Shulock, N., \& Moore, C. (2007). Rules of the game: How state policy creates barriers to degree completion and impedes student success in the California Community Colleges. Sacramento, CA: Institute for Higher Education and Leadership.

Shulock, N., Moore, C., \& Offenstein, J. (2011). The road less traveled: Realizing the potential of career technical education in the California Community Colleges. Sacramento, CA: Institute for Higher Education Leadership \& Policy.

Shulock, N., \& Offenstein, J. (2012). Career opportunities: Career technical education and the college completion agenda, Part 1: Structure and funding of career technical education in the California Community Colleges. Sacramento, CA: Institute for Higher Education and Leadership.

Turner, S. (2004). Going to College and Finishing College: Explaining Different Educational Outcomes, in College Choices: The Economics of Where to Go, When to Go, and How to Pay for It, Hoxby, C. (Editor). Chicago, IL: The University of Chicago Press.

Wolfers, Justin. (2006). "Did Unilateral Divorce Laws Raise Divorce Rates? A Reconciliation and New Results."American Economic Review, 96(5): 1802-1820

Xu, D., \& Trimble, M. (2016). What about certificates? Evidence on the labor market returns to non-degree community college awards in two states. Educational Evaluation and Policy Analysis, 38(2):272-292. 


\section{Figures and Tables}

Figure 1: Log Earnings Event Studies, by Quarters before Completion

All Disciplines Business/Management Health
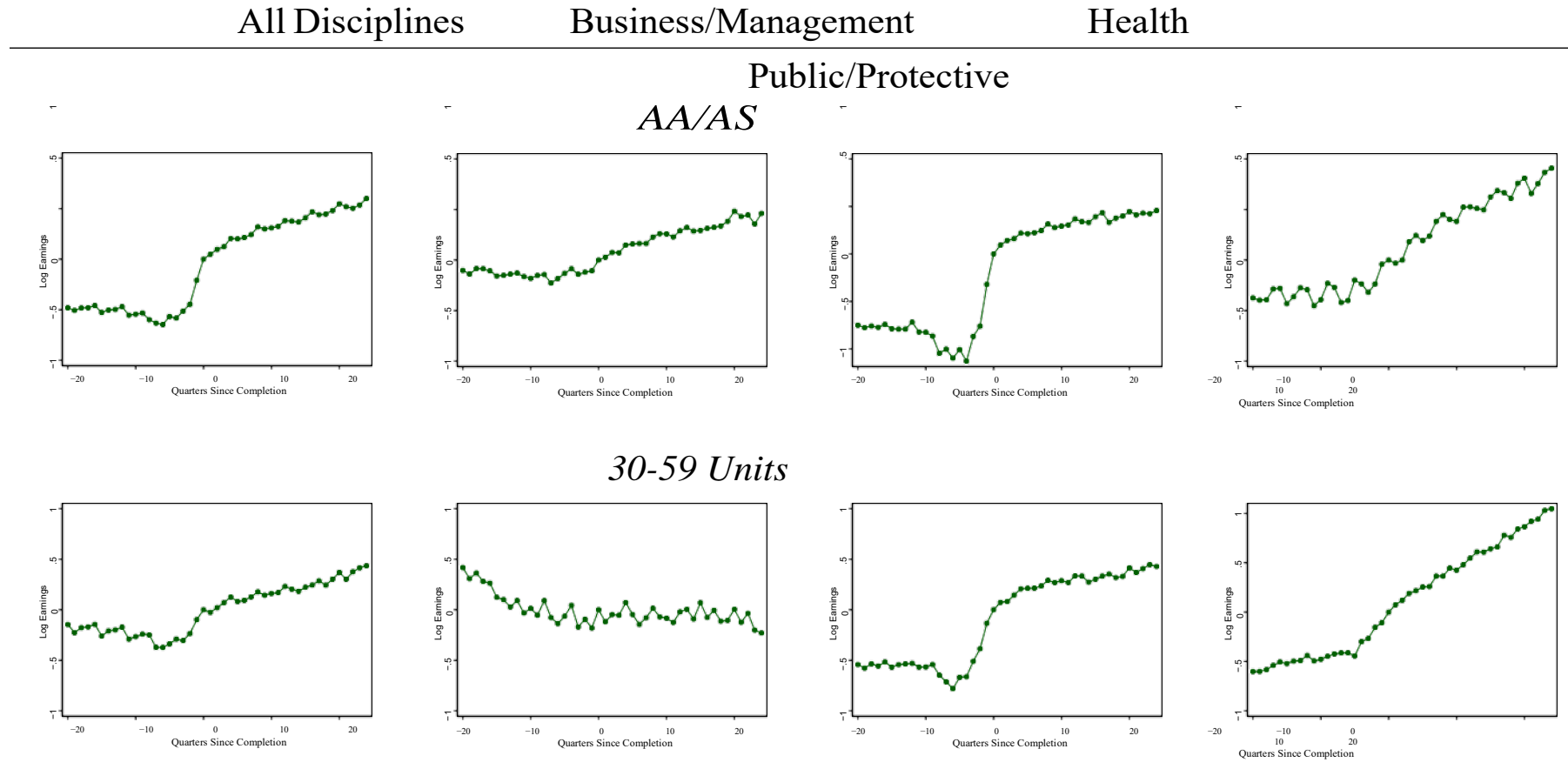

\section{8-29 Units}
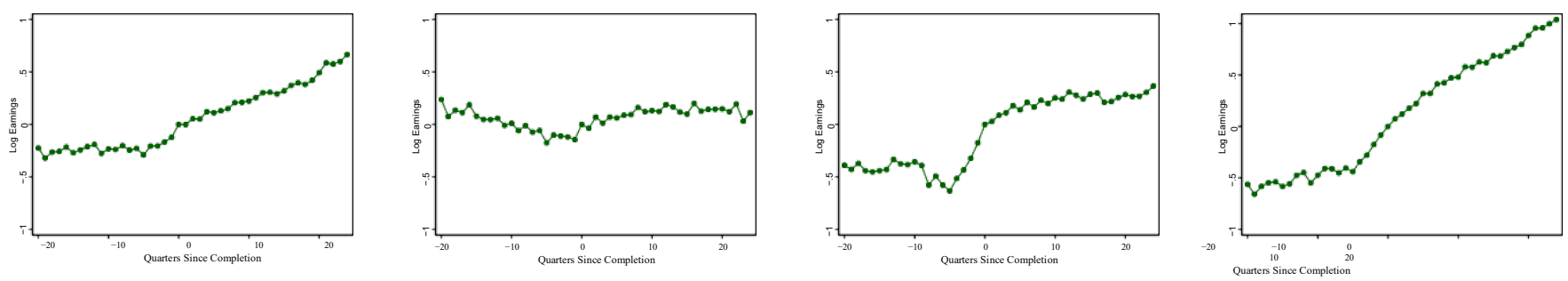

\section{6-17 Units}
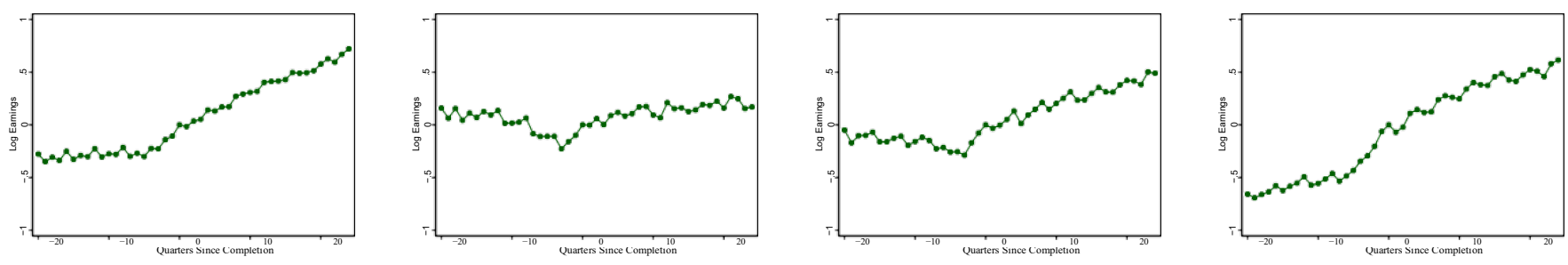

Notes. Figures show coefficients from a regression of log earnings a series of dummy variables for the number of quarters since the student completed the degree. Regressions control for demographics, year effects, quarter effects, and for whether the student was enrolled that quarter. 
Figure 2: Estimates by Award Type, by Subfield and Broad Disciplines
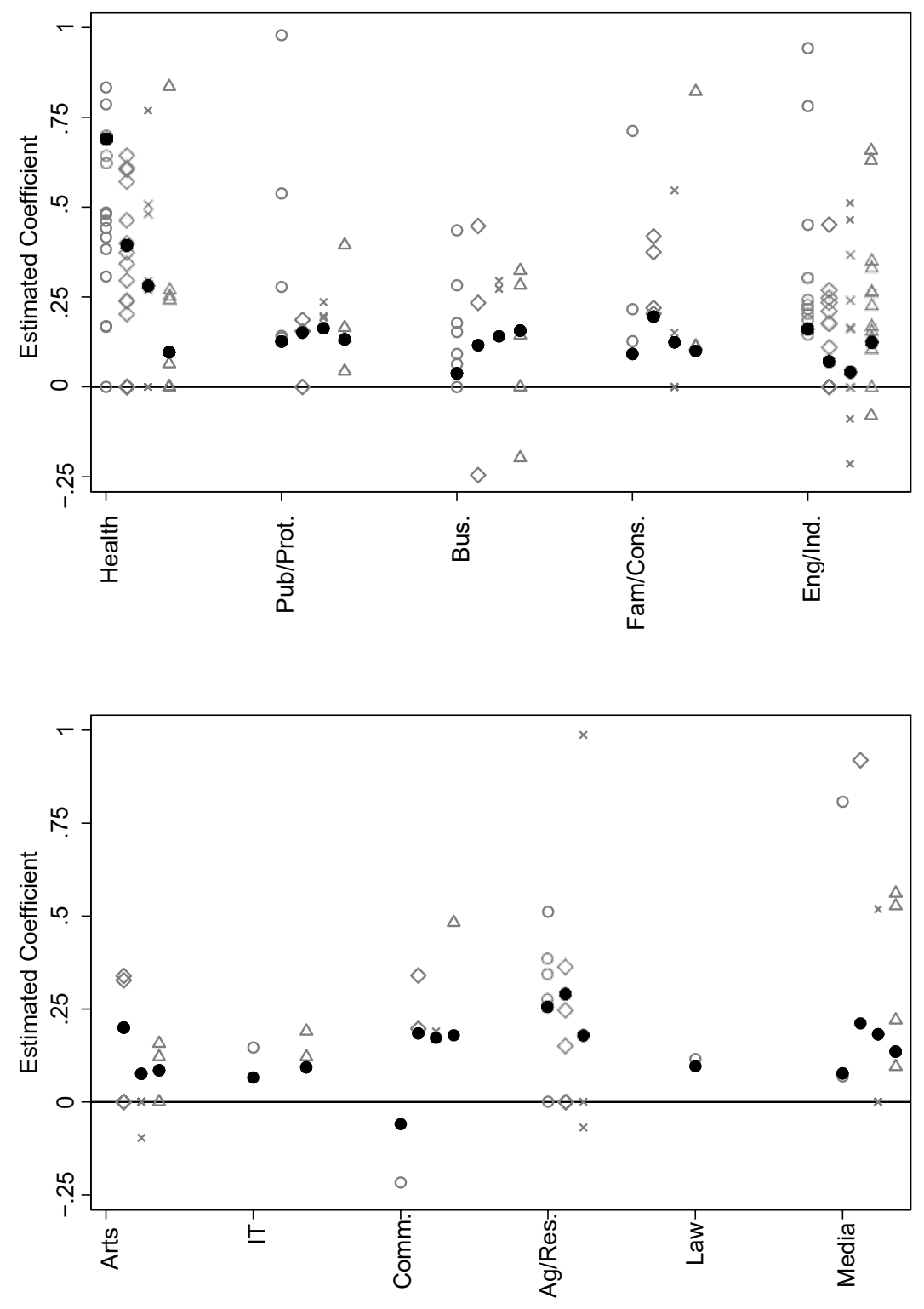

\section{OAA/AS} $\diamond 30-59$ Units $\times 18-29$ Units $\triangle 6-17$ Units

-Discipline-Level

Notes. Gray symbols show coefficients at the subfield level. Black filled-in symbols show coefficients at the larger discipline level. Only coefficients statistically significant at $95 \%$ level are shown, for a total of 200 coefficients. There are 11 coefficients over 1.0 dropped, as well as 7 coefficientsunder-0.3. 
Table 1: Summary Statistics by Discipline

\begin{tabular}{|c|c|c|c|c|c|c|c|c|c|c|c|}
\hline & Health & $\begin{array}{l}\text { Pub/ } \\
\text { Prot }\end{array}$ & Bus & Family & Eng/Ind & Art & IT & Comm & $\mathrm{Ag}$ & Law & Media \\
\hline \multicolumn{12}{|l|}{ A. Awardees } \\
\hline AA/AS & 0.503 & 0.309 & 0.603 & 0.316 & 0.219 & 0.422 & 0.462 & 0.108 & 0.461 & 0.448 & 0.558 \\
\hline 30-59 Unit Cert & 0.179 & 0.139 & 0.0597 & 0.162 & 0.358 & 0.347 & 0.081 & 0.629 & 0.086 & 0.286 & 0.214 \\
\hline 18-29 Unit Cert & 0.045 & 0.136 & 0.158 & 0.132 & 0.192 & 0.103 & 0.142 & 0.140 & 0.128 & 0.201 & 0.097 \\
\hline 6-17 Unit Cert & 0.160 & 0.307 & 0.136 & 0.372 & 0.183 & 0.114 & 0.302 & 0.086 & 0.070 & 0.009 & 0.120 \\
\hline Years to degree & 3.906 & 3.468 & 4.177 & 4.144 & 4.120 & 4.263 & 4.090 & 3.320 & 3.555 & 4.011 & 4.444 \\
\hline Pre-enrollment quarters & 10.72 & 10.16 & 6.821 & 7.513 & 9.983 & 4.896 & 9.130 & 4.954 & 10.88 & 13.95 & 4.876 \\
\hline Employed pre-enrollment & 0.545 & 0.504 & 0.357 & 0.401 & 0.520 & 0.300 & 0.446 & 0.301 & 0.514 & 0.647 & 0.270 \\
\hline Age at enrollment & 27.07 & 25.69 & 28.11 & 29.07 & 26.28 & 23.77 & 29.35 & 21.54 & 30.50 & 34.40 & 24.48 \\
\hline Male & 0.331 & 0.758 & 0.370 & 0.124 & 0.939 & 0.576 & 0.749 & 0.109 & 0.523 & 0.239 & 0.602 \\
\hline White & 0.429 & 0.471 & 0.352 & 0.278 & 0.385 & 0.376 & 0.417 & 0.416 & 0.637 & 0.490 & 0.427 \\
\hline Black & 0.066 & 0.077 & 0.072 & 0.096 & 0.051 & 0.044 & 0.042 & 0.070 & 0.026 & 0.085 & 0.061 \\
\hline Hispanic & 0.206 & 0.291 & 0.228 & 0.373 & 0.331 & 0.219 & 0.190 & 0.290 & 0.142 & 0.200 & 0.175 \\
\hline Asian & 0.094 & 0.030 & 0.230 & 0.139 & 0.101 & 0.221 & 0.199 & 0.120 & 0.050 & 0.075 & 0.199 \\
\hline Observations & 22164 & 15449 & 11799 & 11087 & 12860 & 1454 & 2175 & 5207 & 2064 & 1016 & 1343 \\
\hline \multicolumn{12}{|l|}{ B. Comparison Group } \\
\hline Pre-enrollment quarters & 12.11 & 11.45 & 9.900 & 8.665 & 10.47 & 5.006 & 10.45 & 8.064 & 10.25 & 14.77 & 6.382 \\
\hline Employed pre-enrollment & 0.591 & 0.537 & 0.479 & 0.461 & 0.534 & 0.270 & 0.503 & 0.463 & 0.467 & 0.661 & 0.353 \\
\hline Age at enrollment & 31.67 & 29.23 & 32.33 & 32.58 & 30.60 & 33.20 & 33.97 & 28.42 & 35.58 & 35.11 & 30.77 \\
\hline Male & 0.344 & 0.723 & 0.416 & 0.116 & 0.882 & 0.473 & 0.693 & 0.126 & 0.470 & 0.245 & 0.658 \\
\hline White & 0.409 & 0.440 & 0.366 & 0.330 & 0.338 & 0.451 & 0.373 & 0.400 & 0.643 & 0.346 & 0.466 \\
\hline Black & 0.093 & 0.075 & 0.075 & 0.087 & 0.071 & 0.062 & 0.058 & 0.103 & 0.025 & 0.109 & 0.075 \\
\hline Hispanic & 0.225 & 0.298 & 0.220 & 0.358 & 0.347 & 0.198 & 0.157 & 0.293 & 0.161 & 0.292 & 0.192 \\
\hline Asian & 0.086 & 0.028 & 0.201 & 0.101 & 0.076 & 0.128 & 0.251 & 0.086 & 0.041 & 0.077 & 0.106 \\
\hline Observations & 11989 & 32606 & 39603 & 29738 & 41789 & 42872 & 15755 & 7147 & 4415 & 1541 & 8267 \\
\hline
\end{tabular}

Notes: Each column corresponds to one of the broad disciplines described in the text. Disciplines correspond to two-digit TOP codes as categorized by the CCCCO. Pre-enrollment quarters refer to the number of quarters prior to first enrollment with nonzero earnings. Employed pre-enrollment refers to having at least two quarters of non-zero earnings in the two years prior to first enrollment. 
Table 2: Individual Fixed Effects Results with Trends

\begin{tabular}{lcccc}
\hline & AA/AS & $30-59$ Units & $18-29$ Units & $6-17$ Units \\
\hline Health & $0.690 * * *$ & $0.398 * * *$ & $0.278 * * *$ & $0.114 * * *$ \\
& $(0.0104)$ & $(0.0144)$ & $(0.0296)$ & $(0.0185)$ \\
Public/Protective & $0.153 * * *$ & $0.154 * * *$ & $0.182 * * *$ & $0.140 * * *$ \\
& $(0.0153)$ & $(0.0181)$ & $(0.0168)$ & $(0.0126)$ \\
Business/Management & $0.140 * * *$ & $0.109 * *$ & $0.169 * * *$ & $0.171 * * *$ \\
& $(0.0144)$ & $(0.0410)$ & $(0.0247)$ & $(0.0277)$ \\
Family/Consumer & $0.111 * * *$ & $0.195 * * *$ & $0.116 * * *$ & $0.105 * * *$ \\
& $(0.0183)$ & $(0.0272)$ & $(0.0254)$ & $(0.0277)$ \\
Engineering/Industrial & $0.179 * * *$ & $0.0659 * * *$ & $0.0348 *$ & $0.124 * * *$ \\
& $(0.0175)$ & $(0.0120)$ & $(0.0153)$ & $(0.0180)$ \\
Fine/Applied Arts & $0.187 * *$ & $0.193 * * *$ & 0.141 & $0.298 *$ \\
& $(0.0583)$ & $(0.0562)$ & $(0.120)$ & $(0.138)$ \\
Information Technology & $0.121 * * *$ & 0.0659 & 0.0619 & $0.0940 * *$ \\
& $(0.0343)$ & $(0.0638)$ & $(0.0529)$ & $(0.0326)$ \\
Commercial Services & -0.0483 & $0.184 * * *$ & $0.166 * * *$ & $0.182 * *$ \\
& $(0.0648)$ & $(0.0223)$ & $(0.0453)$ & $(0.0649)$ \\
Agr./Natural Resources & $0.298 * * *$ & $0.324 * * *$ & $0.125 *$ & 0.0337 \\
& $(0.0374)$ & $(0.0803)$ & $(0.0558)$ & $(0.0923)$ \\
Law & $0.171 * * *$ & 0.0751 & 0.0490 & 0.296 \\
& $(0.0416)$ & $(0.0440)$ & $(0.0519)$ & $(0.662)$ \\
Media/Communications & $0.166 * * *$ & $0.188 *$ & 0.220 & 0.143 \\
& $(0.0528)$ & $(0.0890)$ & $(0.147)$ & $(0.115)$ \\
\hline
\end{tabular}

Notes: Each cell corresponds to an individual regression. Sample for each regression consists of students who earned the particular award and qualifying comparison group students, from five years prior to ten years post first enrollment. Outcome variable is log quarterly earnings. Regressions control for individual fixed effects, age dummies, enrollment dummies, year and quarter fixed effects, and individual-specific linear trends. Standard errors clustered at the individual level. ${ }^{*} p<0.05,{ }^{* *} p<0.01,{ }^{* * *} p<0.001$ 
Table 3: Individual Fixed Effects Results with Trends, by Gender

\begin{tabular}{|c|c|c|c|c|}
\hline & $\mathrm{AA} / \mathrm{AS}$ & 30-59 Units & 18-29 Units & 6-17 Units \\
\hline \multicolumn{5}{|l|}{ Female Students } \\
\hline \multirow[t]{2}{*}{ Health } & $0.696 * * *$ & $0.447 * * *$ & $0.268 * * *$ & $0.110 * * *$ \\
\hline & $(0.0123)$ & $(0.0180)$ & $(0.0315)$ & $(0.0242)$ \\
\hline \multirow[t]{2}{*}{ Public/Protective } & $0.167 * * *$ & $0.183 * * *$ & $0.153 * * *$ & 0.0437 \\
\hline & $(0.0298)$ & $(0.0378)$ & $(0.0444)$ & $(0.0308)$ \\
\hline \multirow[t]{2}{*}{ Business/Management } & $0.131 * * *$ & $0.141 * *$ & $0.180 * * *$ & $0.166 * * *$ \\
\hline & $(0.0179)$ & $(0.0465)$ & $(0.0297)$ & $(0.0354)$ \\
\hline \multirow[t]{2}{*}{ Family/Consumer } & $0.106 * * *$ & $0.211 * * *$ & $0.122 * * *$ & $0.109 * * *$ \\
\hline & $(0.0191)$ & $(0.0326)$ & $(0.0279)$ & $(0.0168)$ \\
\hline \multirow[t]{2}{*}{ Engineering/Industrial } & $0.259 * * *$ & 0.0872 & 0.133 & $0.152 *$ \\
\hline & $(0.0700)$ & $(0.0614)$ & $(0.0870)$ & $(0.0638)$ \\
\hline \multirow[t]{2}{*}{ Fine/Applied Arts } & 0.187 & 0.105 & $0.356 *$ & 0.274 \\
\hline & $(0.102)$ & $(0.0707)$ & $(0.178)$ & $(0.230)$ \\
\hline \multirow[t]{2}{*}{ Information Technology } & 0.0524 & $0.255 *$ & 0.154 & 0.0778 \\
\hline & $(0.0837)$ & $(0.0995)$ & $(0.128)$ & $(0.0755)$ \\
\hline \multirow[t]{2}{*}{ Commercial Services } & 0.00720 & $0.179 * * *$ & $0.152 * * *$ & $0.161 *$ \\
\hline & $(0.0908)$ & $(0.0231)$ & $(0.0457)$ & $(0.0682)$ \\
\hline \multirow[t]{2}{*}{ Agr./Natural Resources } & $0.301 * * *$ & $0.371 * *$ & 0.0983 & -0.0428 \\
\hline & $(0.0468)$ & $(0.127)$ & $(0.119)$ & $(0.147)$ \\
\hline \multirow[t]{2}{*}{ Law } & $0.164 * * *$ & 0.0858 & 0.00817 & 0.308 \\
\hline & $(0.0483)$ & $(0.0454)$ & $(0.0573)$ & $(0.661)$ \\
\hline \multirow[t]{2}{*}{ Media/Communications } & $0.179 *$ & 0.153 & 0.203 & 0.236 \\
\hline & $(0.0834)$ & $(0.146)$ & $(0.320)$ & $(0.203)$ \\
\hline \multicolumn{5}{|l|}{ Male Students } \\
\hline \multirow[t]{2}{*}{ Health } & $0.669 * * *$ & $0.314 * * *$ & $0.320 * * *$ & $0.118 * * *$ \\
\hline & $(0.0193)$ & $(0.0238)$ & $(0.0776)$ & $(0.0287)$ \\
\hline \multirow[t]{2}{*}{ Public/Protective } & $0.148 * * *$ & $0.144 * * * *$ & $0.189 * * *$ & $0.161 * * *$ \\
\hline & $(0.0178)$ & $(0.0207)$ & $(0.0181)$ & $(0.0137)$ \\
\hline \multirow[t]{2}{*}{ Business/Management } & $0.156 * * *$ & 0.00590 & $0.144 * *$ & $0.179 * * *$ \\
\hline & $(0.0246)$ & $(0.0851)$ & $(0.0441)$ & $(0.0439)$ \\
\hline \multirow[t]{2}{*}{ Family/Consumer } & $0.169 * *$ & $0.162 * * *$ & 0.0863 & 0.0675 \\
\hline & $(0.0640)$ & $(0.0485)$ & $(0.0625)$ & $(0.0521)$ \\
\hline \multirow[t]{2}{*}{ Engineering/Industrial } & $0.172 * * *$ & $0.0660 * * *$ & $0.0313 *$ & $0.122 * * *$ \\
\hline & $(0.0181)$ & $(0.0123)$ & $(0.0155)$ & $(0.0188)$ \\
\hline \multirow[t]{2}{*}{ Fine/Applied Arts } & $0.187 * *$ & $0.221 * *$ & -0.0449 & 0.305 \\
\hline & $(0.0658)$ & $(0.0723)$ & $(0.164)$ & $(0.171)$ \\
\hline \multirow[t]{2}{*}{ Information Technology } & $0.140 * * *$ & -0.0366 & 0.0413 & $0.0985 * *$ \\
\hline & $(0.0374)$ & $(0.0787)$ & $(0.0572)$ & $(0.0361)$ \\
\hline \multirow[t]{2}{*}{ Commercial Services } & -0.0598 & $0.241 * *$ & 0.424 & 0.342 \\
\hline & $(0.0925)$ & $(0.0878)$ & $(0.276)$ & $(0.209)$ \\
\hline \multirow[t]{2}{*}{ Agr./Natural Resources } & $0.278 * * *$ & $0.306 * *$ & $0.144 *$ & 0.114 \\
\hline & $(0.0612)$ & $(0.105)$ & $(0.0591)$ & $(0.106)$ \\
\hline \multirow[t]{2}{*}{ Law } & $0.200 *$ & 0.0491 & 0.219 & \\
\hline & $(0.0842)$ & $(0.112)$ & $(0.115)$ & \\
\hline Media/Communications & $0.158 *$ & 0.213 & 0.234 & 0.0608 \\
\hline & $(0.0677)$ & $(0.112)$ & $(0.120)$ & $(0.130)$ \\
\hline
\end{tabular}

Notes: Each cell corresponds to an individual regression. Sample for each regression consists of students who earned the particular award and qualifying comparison group students, from five years prior to ten years post first enrollment. Outcome variable is log quarterly earnings. Regressions control for individual fixed effects, age dummies, enrollment dummies, year and quarter fixed effects, and individual-specific linear trends. Standard errors clustered at the individual level. ${ }^{*} p<0.05, * * p<0.01,{ }^{* * *} p<0.001$ 
Table 4: Estimated Returns by Award Length

\begin{tabular}{lccc}
\hline & Overall & Men & Women \\
\cline { 2 - 4 } A. Full Sample & & & \\
AA/AS & $0.372 * * *$ & $0.374 * * *$ & $0.343 * * *$ \\
& $(0.015)$ & $(0.032)$ & $(0.028)$ \\
30-59 Unit Certificate & $0.247 * * *$ & $0.201 * * *$ & $0.263 * * *$ \\
& $(0.016)$ & $(0.027)$ & $(0.067)$ \\
18-29 Unit Certificate & $0.167 * * *$ & $0.148 * * *$ & $0.184 * * *$ \\
& $(0.017)$ & $(0.049)$ & $(0.060)$ \\
6-17 Unit Certificate & $0.134 * * *$ & $0.133 * * *$ & $0.096 * * *$ \\
& $(0.011)$ & $(0.036)$ & $(0.028)$ \\
B. Excluding Health & & & \\
AA/AS & $0.203 * * *$ & $0.230 * * *$ & $0.159 * * *$ \\
& $(0.018)$ & $(0.047)$ & $(0.040)$ \\
30-59 Unit Certificate & $0.178 * * *$ & $0.133 * * *$ & $0.186 * * *$ \\
& $(0.020)$ & $(0.029)$ & $(0.091)$ \\
18-29 Unit Certificate & $0.155 * * *$ & $0.139 * * *$ & $0.173 * * *$ \\
& $(0.018)$ & $(0.047)$ & $(0.068)$ \\
6-17 Unit Certificate & $0.139 * * *$ & $0.148 * * *$ & $0.090 * * *$ \\
& $(0.013)$ & $(0.041)$ & $(0.033)$ \\
\hline
\end{tabular}

Notes: Each cell corresponds to a weighted average of estimate returns at the award-length and subfield level. Estimates are weighted by the number of awards in each award type. Standard errors calculated using bootstrap method with 50 iterations. ${ }^{*} p<0.05,{ }^{* *} p<0.01,{ }^{* * *} p<0.001$ 
Table 5: Specification Checks for Including Individual-Specific Linear Time Trends

\begin{tabular}{|c|c|c|c|c|}
\hline & \multirow[b]{2}{*}{$\begin{array}{l}\text { Test for differential } \\
\text { pre-enrollment trends }\end{array}$} & \multicolumn{3}{|c|}{ Coefficients on completion } \\
\hline & & No Trends & Trends & $\begin{array}{c}(2)-(3) \\
\text { statistically } \\
\text { significant }\end{array}$ \\
\hline & (1) & (2) & (3) & (4) \\
\hline \multicolumn{5}{|l|}{ Health } \\
\hline AAAS & $0.001(0.001)$ & $0.67(0.01)$ & $0.69(0.01)$ & \\
\hline 30-60 units & $-0.014 * * *(0.004)$ & $0.33(0.01)$ & $0.40(0.01)$ & YES \\
\hline 18-29 units & $-0.012(0.008)$ & $0.14(0.03)$ & $0.28(0.03)$ & YES \\
\hline 6-17 units & $-0.002(0.004)$ & $0.02(0.02)$ & $0.11(0.02)$ & YES \\
\hline \multicolumn{5}{|c|}{ Engineering/Industrial } \\
\hline AAAS & $-0.007(0.01)$ & $0.22(0.02)$ & $0.18(0.02)$ & \\
\hline 30-60 units & $-0.004(0.005)$ & $0.13(0.01)$ & $0.07(0.01)$ & YES \\
\hline 18-29 units & $-0.002(0.005)$ & $0.08(0.01)$ & $0.03(0.02)$ & \\
\hline 6-17 units & $-0.002(0.004)$ & $0.07(0.02)$ & $0.12(0.02)$ & \\
\hline \multicolumn{5}{|c|}{ Public/Protective } \\
\hline AAAS & $-0.007(0.007)$ & $0.19(0.01)$ & $0.15(0.02)$ & \\
\hline 30-60 units & $-0.013 *(0.006)$ & $0.19(0.02)$ & $0.15(0.02)$ & \\
\hline 18-29 units & $-0.005(0.004)$ & $0.17(0.02)$ & $0.18(0.02)$ & \\
\hline 6-17 units & $0.001(0.003)$ & $0.21(0.01)$ & $0.14(0.01)$ & YES \\
\hline \multicolumn{5}{|c|}{ Family/Consumer } \\
\hline AAAS & $-0.021 *(0.01)$ & $0.14(0.02)$ & $0.11(0.02)$ & \\
\hline 30-60 units & $-0.005(0.009)$ & $0.10(0.02)$ & $0.20(0.03)$ & YES \\
\hline 18-29 units & $-0.020 *(0.009)$ & $0.10(0.02)$ & $0.12(0.03)$ & \\
\hline 6-17 units & $0.003(0.005)$ & $0.09(0.01)$ & $0.11(0.02)$ & \\
\hline \multicolumn{5}{|c|}{ Information Technology } \\
\hline AAAS & $-0.014(0.014)$ & $0.10(0.03)$ & $0.12(0.03)$ & \\
\hline 30-60 units & $0.067(0.039)$ & $0.09(0.06)$ & $0.07(0.06)$ & \\
\hline 18-29 units & $0.028 *(0.014)$ & $0.05(0.05)$ & $0.06(0.05)$ & \\
\hline 6-17 units & $0.007(0.01)$ & $0.08(0.03)$ & $0.09(0.03)$ & \\
\hline \multicolumn{5}{|c|}{ Commercial Services } \\
\hline AAAS & $0.019(0.023)$ & $-0.05(0.06)$ & $-0.05(0.06)$ & \\
\hline 30-60 units & $0.006(0.007)$ & $0.03(0.02)$ & $0.18(0.02)$ & YES \\
\hline 18-29 units & $0.017(0.01)$ & $0.07(0.04)$ & $0.17(0.05)$ & \\
\hline 6-17 units & $-0.02(0.012)$ & $0.13(0.05)$ & $0.18(0.06)$ & \\
\hline
\end{tabular}

Notes. Estimates in column 1 are from a regression of log earnings on degree completion, quarters to degree, and the interaction of these two variables, as proposed in Dynarski, Jacob and Kreisman (2016). The coefficients shown are the interaction between award completion and quarters to completion. Columns 2 and 3 show the main estimates with and without individual trends, and column 4 shows whether the difference is statistically significant. ${ }^{*} p<0.05,{ }^{*} p<0.01,{ }^{* * *} p<0.001$ 
Table 6: Estimated Returns by Award Length, Comparison with OLS

\begin{tabular}{lccc}
\hline & OLS & FE & diff/p-value \\
\hline A. Full Sample & & & \\
AA/AS & $0.251^{* * *}$ & $0.181^{* * *}$ & 0.070 \\
& $(0.027)$ & $(0.029)$ & 0.074 \\
30-59 Unit Certificate & $0.167^{* * *}$ & $0.183^{* * *}$ & -0.016 \\
& $(0.032)$ & $(0.033)$ & 0.728 \\
18-29 Unit Certificate & $0.138^{* * *}$ & $0.205^{* * *}$ & -0.067 \\
& $(0.038)$ & $(0.050)$ & 0.285 \\
6-17 Unit Certificate & $0.231^{* * *}$ & $0.114^{* * *}$ & 0.117 \\
& $(0.029)$ & $(0.033)$ & 0.007 \\
B. Excluding Health & & & \\
AA/AS & & & \\
& $0.180^{* * *}$ & $0.090^{* * *}$ & 0.090 \\
30-59 Unit Certificate & $(0.028)$ & $(0.031)$ & 0.032 \\
& $0.123 * * *$ & $0.163 * * *$ & -0.040 \\
18-29 Unit Certificate & $(0.034)$ & $(0.037)$ & 0.426 \\
& $0.134^{* * *}$ & $0.187 * * *$ & -0.053 \\
6-17 Unit Certificate & $(0.039)$ & $(0.053)$ & 0.422 \\
& $0.205^{* * *}$ & $0.099 * * *$ & 0.106 \\
& $(0.034)$ & $(0.039)$ & 0.040 \\
\hline
\end{tabular}

Notes: Each cell corresponds to a weighted average of estimate returns at the award- length and discipline level. Estimates are weighted by the number of awards in each award type. Standard errors calculated using bootstrap method with 300 iterations. OLS specifications include controls for 11 th grade math and English language arts (ELA) scores, as well as parental education level. P-values come from a Hausman test of the two specifications. Standard errors clustered by individual. ${ }^{*} p<0.05,{ }^{* *} p$ $<0.01,{ }^{* * *} p<0.0$ 


\section{A1 Appendix Figures and Tables}

Figure A1: Number of Awards Granted, 1996-2013 (thousands)

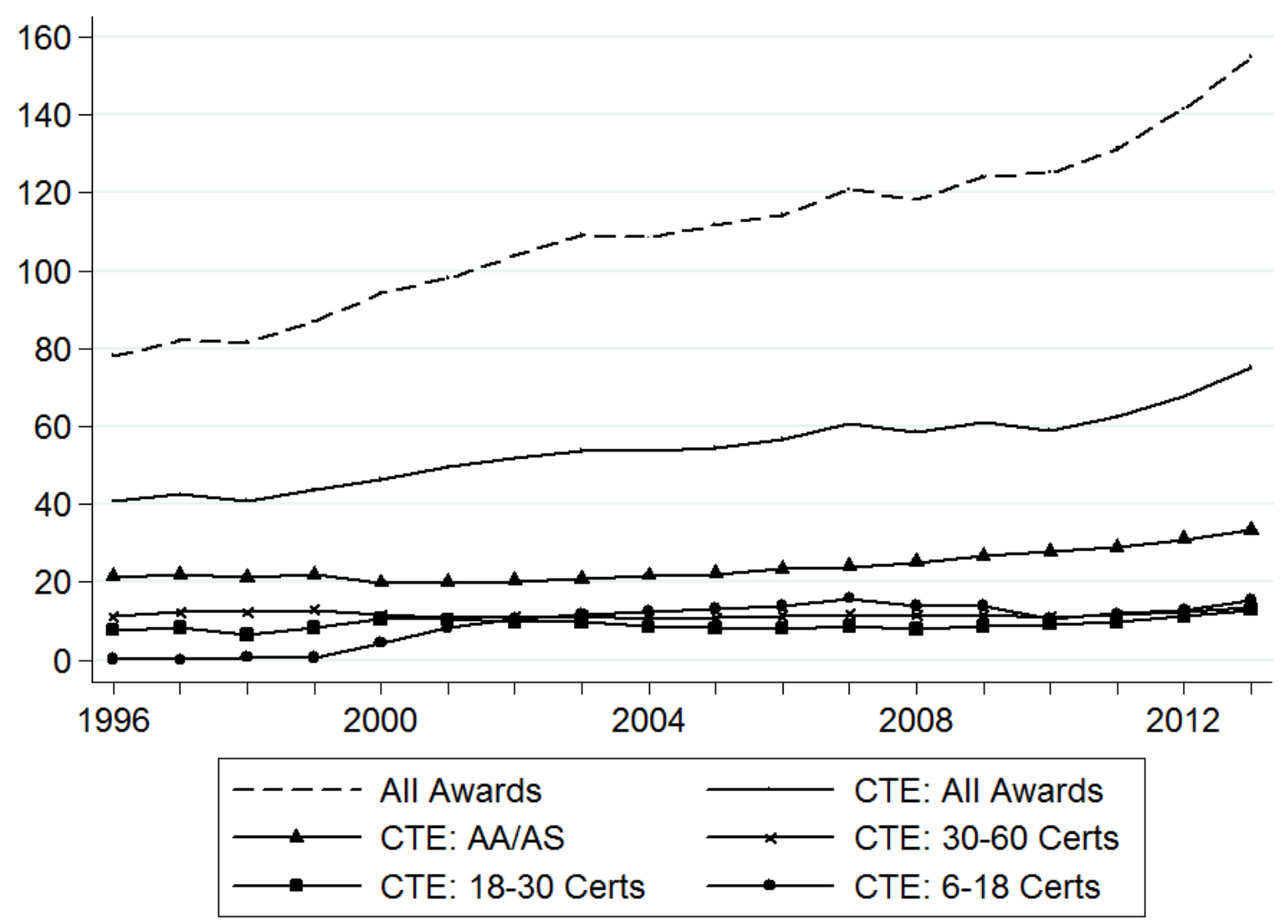


Figure A2: Units Earned in First 3 Years in Same Discipline

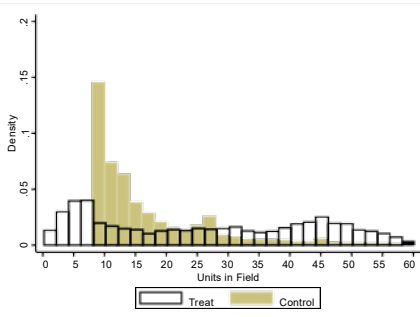

Health

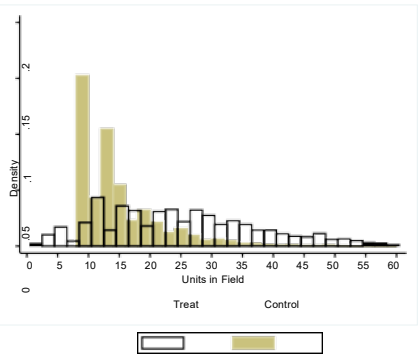

Family/Consumer

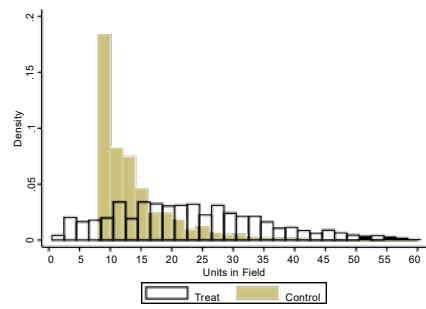

Information Technology

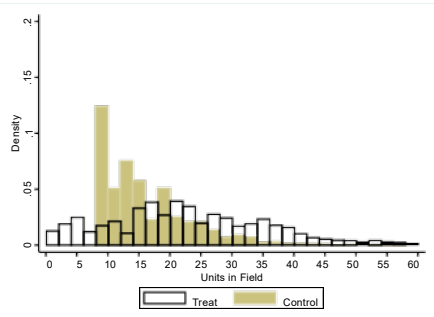

Public/Protective

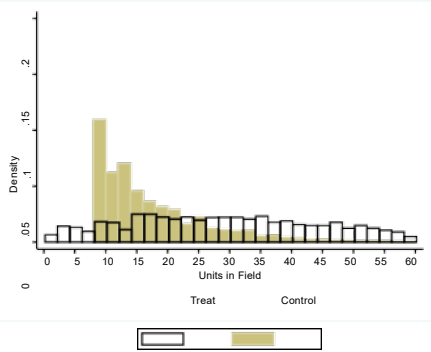

Engineering/Industrial

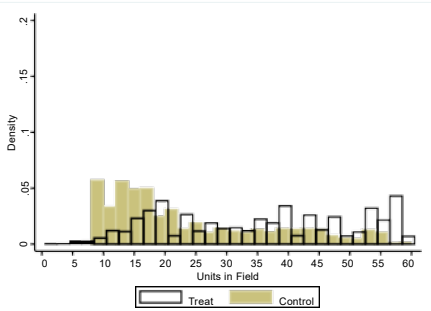

Commercial Services

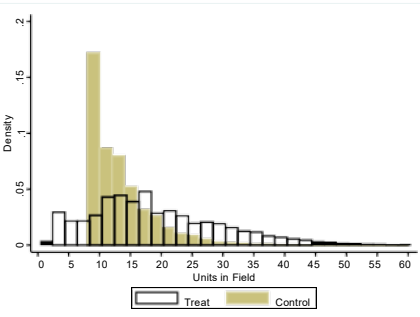

Business/Management

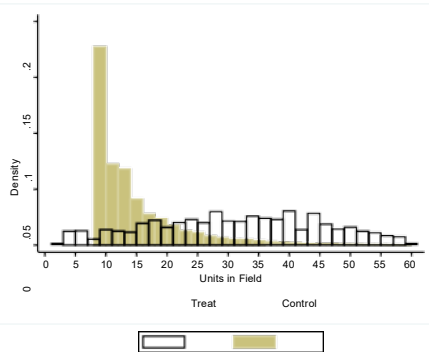

Fine/Applied Arts

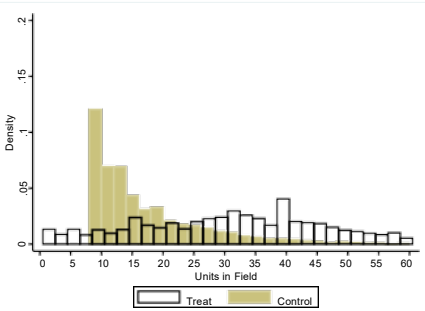

Agr/Natural Resources

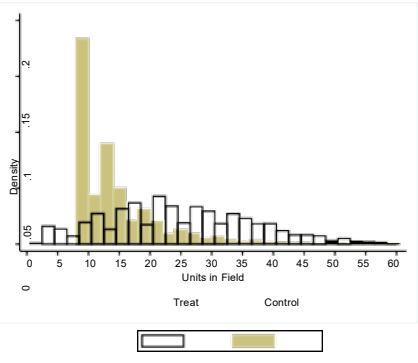

Media/Communications

Histograms show units accumulated within the same discipline in the first three years since enrollment in any community college. Students with over 60 units in the first three years are dropped. 
Figure A3: Estimates by Award Type, by Subfield and Broad Disciplines, Including Statistically Insignificant Results
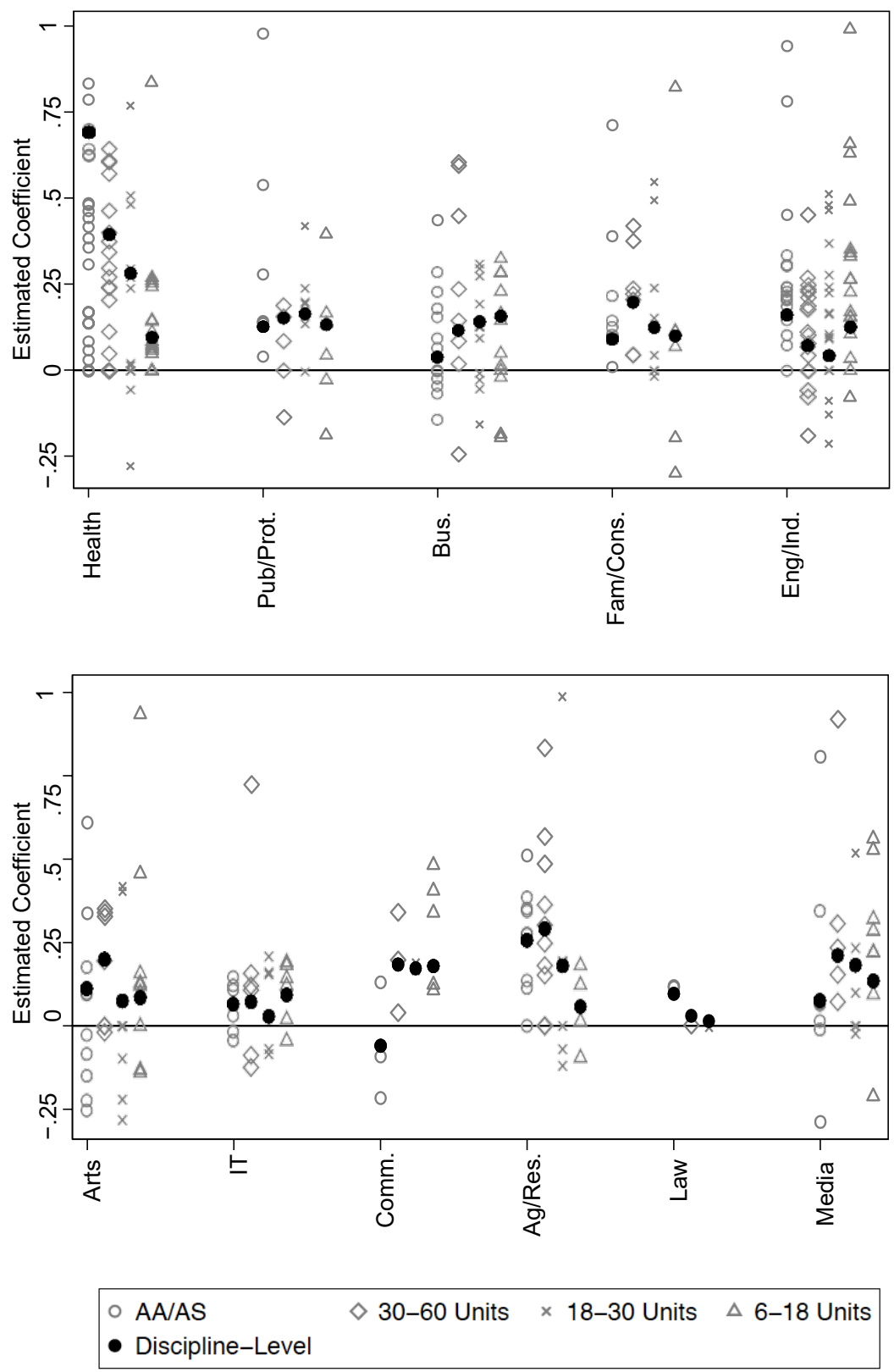

Notes. Gray symbols show coefficients at the subfield level. Black filled-in symbols show coefficients at the larger discipline level. All coefficients are shown, regardless of statistical significance, except for 11 coefficients over 1.0 dropped, as well as 7 coefficients under -0.3 . 
Table A1: Specifications with Dynamic Treatment Effects, Selected Disciplines

\begin{tabular}{|c|c|c|c|c|c|c|c|c|}
\hline \multirow{2}{*}{$\underline{\text { A. Health }}$} & \multicolumn{4}{|c|}{ Trends } & \multicolumn{4}{|c|}{$\underline{\text { Without Trends }}$} \\
\hline & $\mathrm{AA} / \mathrm{AS}$ & 30-59 Units & 18-29 Units & \multirow[t]{2}{*}{ 6-17 Units } & \multirow[t]{2}{*}{$\mathrm{AA} / \mathrm{AS}$} & \multicolumn{2}{|c|}{ 30-59 Units 18-29 Units } & \multirow[t]{2}{*}{ 6-17 Units } \\
\hline & & & & & & & & \\
\hline Main Results & & & & & & & & \\
\hline Post-Completion & $\begin{array}{l}0.690 * * * \\
(0.0104)\end{array}$ & $\begin{array}{l}0.398 * * * \\
(0.0144)\end{array}$ & $\begin{array}{l}0.278 * * * \\
(0.0296)\end{array}$ & $\begin{array}{l}0.114 * * * \\
(0.0185)\end{array}$ & $\begin{array}{l}0.667 * * * \\
(0.010)\end{array}$ & $\begin{array}{l}0.334 * * * \\
(0.0132)\end{array}$ & $\begin{array}{l}0.140 * * * \\
(0.0277)\end{array}$ & $\begin{array}{l}0.0241 \\
(0.0166)\end{array}$ \\
\hline \multicolumn{9}{|l|}{ Step Function } \\
\hline Years $0-1$ & $\begin{array}{l}0.617 * * * \\
(0.00961)\end{array}$ & $\begin{array}{l}0.359 * * * \\
(0.0138)\end{array}$ & $\begin{array}{l}0.244 * * * \\
(0.0278)\end{array}$ & $\begin{array}{l}0.119 * * * \\
(0.0170)\end{array}$ & $\begin{array}{l}0.668 * * * \\
(0.010)\end{array}$ & $\begin{array}{l}0.361 * * * \\
(0.0128)\end{array}$ & $\begin{array}{l}0.180 * * * \\
(0.0264)\end{array}$ & $\begin{array}{l}0.0171 \\
(0.0164)\end{array}$ \\
\hline Years 2-3 & $\begin{array}{l}0.607 * * * \\
(0.0147)\end{array}$ & $\begin{array}{l}0.300 * * * \\
(0.0213)\end{array}$ & $\begin{array}{l}0.240 * * * \\
(0.0418)\end{array}$ & $\begin{array}{l}0.171 * * * \\
(0.0261)\end{array}$ & $\begin{array}{l}0.666 * * * \\
(0.0134)\end{array}$ & $\begin{array}{l}0.295 * * * \\
(0.0171)\end{array}$ & $\begin{array}{l}0.120 * * * \\
(0.0331)\end{array}$ & $\begin{array}{l}0.0339 \\
(0.0203)\end{array}$ \\
\hline Years 4+ & $\begin{array}{l}0.620 * * * \\
(0.0230)\end{array}$ & $\begin{array}{l}0.280 * * * \\
(0.0314)\end{array}$ & $\begin{array}{l}0.216 * * * \\
(0.0608)\end{array}$ & $\begin{array}{l}0.217 * * * \\
(0.0370)\end{array}$ & $\begin{array}{l}0.635 * * * \\
(0.0203)\end{array}$ & $\begin{array}{l}0.240 * * * \\
(0.0238)\end{array}$ & $\begin{array}{l}-0.00725 \\
(0.0535)\end{array}$ & $\begin{array}{l}0.0319 \\
(0.0273)\end{array}$ \\
\hline F-Test of Equality & 1.139 & 9.229 & 0.231 & 6.058 & 2.543 & 19.82 & 8.233 & 0.604 \\
\hline p-value of Test & 0.320 & 0.000 & 0.793 & 0.002 & 0.0787 & 0.000 & 0.000 & 0.547 \\
\hline \multicolumn{9}{|l|}{ B. Public/Protective } \\
\hline $\begin{array}{l}\text { Main Results } \\
\text { Post-Completion }\end{array}$ & $\begin{array}{l}0.153 * * * \\
(0.0153)\end{array}$ & $\begin{array}{l}0.154 * * * \\
(0.0181)\end{array}$ & $\begin{array}{l}0.182 * * * \\
(0.0168)\end{array}$ & $\begin{array}{l}0.140 * * * \\
(0.0126)\end{array}$ & $\begin{array}{l}0.188 * * * * \\
(0.0139)\end{array}$ & $\begin{array}{l}0.186 * * * \\
(0.0162)\end{array}$ & $\begin{array}{l}0.171 * * * \\
(0.0159)\end{array}$ & $\begin{array}{l}0.209 * * * \\
(0.0121)\end{array}$ \\
\hline \multicolumn{9}{|l|}{ Step Function } \\
\hline Years 0-1 & $\begin{array}{l}0.156 * * * \\
(0.0143)\end{array}$ & $\begin{array}{l}0.150 * * * * \\
(0.0172)\end{array}$ & $\begin{array}{l}0.164 * * * * \\
(0.0165)\end{array}$ & $\begin{array}{l}0.128 * * * \\
(0.0125)\end{array}$ & $\begin{array}{l}0.145 * * * \\
(0.0133)\end{array}$ & $\begin{array}{l}0.172 * * * * \\
(0.0162)\end{array}$ & $\begin{array}{l}0.166 * * * \\
(0.0160)\end{array}$ & $\begin{array}{l}0.201 * * * \\
(0.0117)\end{array}$ \\
\hline Years 2-3 & $\begin{array}{l}0.257 * * * \\
(0.0248)\end{array}$ & $\begin{array}{l}0.169 * * * \\
(0.0270)\end{array}$ & $\begin{array}{l}0.141 * * * \\
(0.0249)\end{array}$ & $\begin{array}{l}0.0880 * * * \\
(0.0191)\end{array}$ & $\begin{array}{l}0.277 * * * \\
(0.0201)\end{array}$ & $\begin{array}{l}0.199 * * * \\
(0.0206)\end{array}$ & $\begin{array}{l}0.172 * * * \\
(0.0190)\end{array}$ & $\begin{array}{l}0.219 * * * \\
(0.0141)\end{array}$ \\
\hline Years 4+ & $\begin{array}{l}0.328 * * * \\
(0.0393)\end{array}$ & $\begin{array}{l}0.206 * * * \\
(0.0386)\end{array}$ & $\begin{array}{l}0.121 * * * \\
(0.0350)\end{array}$ & $\begin{array}{l}0.0870 * * \\
(0.0272)\end{array}$ & $\begin{array}{l}0.337 * * * \\
(0.0327)\end{array}$ & $\begin{array}{l}0.217 * * * * \\
(0.0250)\end{array}$ & $\begin{array}{l}0.187 * * * \\
(0.0218)\end{array}$ & $\begin{array}{l}0.217 * * * \\
(0.0189)\end{array}$ \\
\hline F-Test of Equality & 18.50 & 1.784 & 1.352 & 6.462 & 36.68 & 2.261 & 0.612 & 1.665 \\
\hline p-value of Test & 0.000 & 0.168 & 0.259 & 0.002 & 0.000 & 0.104 & 0.542 & 0.189 \\
\hline \multicolumn{9}{|l|}{ C. Business } \\
\hline \multicolumn{9}{|l|}{ Main Results } \\
\hline Post-Completion & $\begin{array}{l}0.140 * * * \\
(0.0144)\end{array}$ & $\begin{array}{l}0.109 * * \\
(0.0410)\end{array}$ & $\begin{array}{l}0.169 * * * \\
(0.0247)\end{array}$ & $\begin{array}{l}0.171 * * * \\
(0.0277)\end{array}$ & $\begin{array}{l}0.139 * * * \\
(0.0134)\end{array}$ & $\begin{array}{l}0.134 * * * \\
(0.0389)\end{array}$ & $\begin{array}{l}0.199 * * * \\
(0.0219)\end{array}$ & $\begin{array}{l}0.0891 * * * \\
(0.0235)\end{array}$ \\
\hline \multicolumn{9}{|l|}{ Step Function } \\
\hline Years $0-1$ & $\begin{array}{l}0.117 \text { *** } \\
(0.0123)\end{array}$ & $\begin{array}{l}0.0917 * \\
(0.0363)\end{array}$ & $\begin{array}{l}0.154 * * * \\
(0.0218)\end{array}$ & $\begin{array}{l}0.154 * * * \\
(0.0239)\end{array}$ & $\begin{array}{l}0.124 * * * \\
(0.0128)\end{array}$ & $\begin{array}{l}0.103 * * \\
(0.0368)\end{array}$ & $\begin{array}{l}0.153 * * * \\
(0.0214)\end{array}$ & $\begin{array}{l}0.0789 * * * \\
(0.0233)\end{array}$ \\
\hline Years 2-3 & $\begin{array}{l}0.117 \text { *** } \\
(0.0207)\end{array}$ & $\begin{array}{l}0.0978 \\
(0.0587)\end{array}$ & $\begin{array}{l}0.206 * * * \\
(0.0321)\end{array}$ & $\begin{array}{l}0.167 * * * \\
(0.0376)\end{array}$ & $\begin{array}{l}0.175 * * * \\
(0.0195)\end{array}$ & $\begin{array}{l}0.181 * * * \\
(0.0519)\end{array}$ & $\begin{array}{l}0.255 * * * \\
(0.0279)\end{array}$ & $\begin{array}{l}0.101 * * * \\
(0.0301)\end{array}$ \\
\hline Years 4+ & $\begin{array}{l}0.100 * * \\
(0.0337)\end{array}$ & $\begin{array}{l}0.0664 \\
(0.0926)\end{array}$ & $\begin{array}{l}0.230 * * * \\
(0.0478)\end{array}$ & $\begin{array}{l}0.199 * * * * \\
(0.0527)\end{array}$ & $\begin{array}{l}0.180 * * * \\
(0.0348)\end{array}$ & $\begin{array}{l}0.209 * * \\
(0.0771)\end{array}$ & $\begin{array}{l}0.316 * * * \\
(0.0385)\end{array}$ & $\begin{array}{l}0.108 * \\
(0.0436)\end{array}$ \\
\hline F-Test of Equality & 0.208 & 0.114 & 3.394 & 0.525 & 5.349 & 2.359 & 15.19 & 0.452 \\
\hline p-value of Test & 0.812 & 0.892 & 0.0336 & 0.592 & 0.005 & 0.0945 & 0.000 & 0.636 \\
\hline
\end{tabular}

The "main results" correspond to a regression of log earnings on an individual fixed effect, controls for enrollment, and year and age effects. The "step functions" display estimates of the coefficient on three dummy variables for elapsed time since degree or certificate completion, with the omitted category being pre-completion quarters. Standard errors clustered at the individual level. $* p<0.05, * * p<0.01, * * * p<0.001$ 
Table A1: Specifications with Dynamic Treatment Effects, Selected Disciplines (cont.)

\begin{tabular}{|c|c|c|c|c|c|c|c|c|}
\hline \multirow{4}{*}{$\begin{array}{l} \\
\text { D. Family/Consumer } \\
\text { Main Results }\end{array}$} & \multicolumn{4}{|c|}{$\underline{\text { Trends }}$} & \multicolumn{4}{|c|}{ Without Trends } \\
\hline & \multirow[t]{2}{*}{$\mathrm{AA} / \mathrm{AS}$} & \multirow[t]{2}{*}{ 30-59 Units } & \multirow[t]{2}{*}{$18-29$ Units } & \multirow[t]{2}{*}{ 6-17 Units } & \multirow[t]{2}{*}{$\mathrm{AA} / \mathrm{AS}$} & \multirow[t]{2}{*}{ 30-59 Units } & \multirow[t]{2}{*}{ 18-29 Units } & \multirow[t]{2}{*}{ 6-17 Units } \\
\hline & & & & & & & & \\
\hline & & & & & & & & \\
\hline Post-Completion & $\begin{array}{c}0.111 \\
(0.0183)\end{array}$ & $\begin{array}{l}0.195 * * * \\
(0.0272)\end{array}$ & $\begin{array}{l}0.116 * * * \\
(0.0254)\end{array}$ & $\begin{array}{l}0.105 * * * \\
(0.0160)\end{array}$ & $\begin{array}{c}0.144 * * * \\
(0.0162)\end{array}$ & $\begin{array}{c}0.0959 * * * \\
(0.0241)\end{array}$ & $\begin{array}{c}0.0993 * * * \\
(0.0222)\end{array}$ & $\begin{array}{c}0.0883 * * * \\
(0.0148)\end{array}$ \\
\hline Step Function & & & & & & & & \\
\hline Years 0-1 & $\begin{array}{c}0.0976 * * * \\
(0.0157)\end{array}$ & $\begin{array}{l}0.178 * * * \\
(0.0244)\end{array}$ & $\begin{array}{l}0.107 * * * \\
(0.0225)\end{array}$ & $\begin{array}{c}0.0875 * * * \\
(0.0140)\end{array}$ & $\begin{array}{l}0.139 * * * \\
(0.0155)\end{array}$ & $\begin{array}{l}0.0931 * * * \\
(0.0231)\end{array}$ & $\begin{array}{l}0.0957 * * * * \\
(0.0215)\end{array}$ & $\begin{array}{c}0.0802 * * * * \\
(0.0144)\end{array}$ \\
\hline Years 2-3 & $\begin{array}{l}0.127 * * * \\
(0.0277)\end{array}$ & $\begin{array}{l}0.222 * * * \\
(0.0423)\end{array}$ & $\begin{array}{l}0.111 * * \\
(0.0360)\end{array}$ & $\begin{array}{l}0.107 * * * \\
(0.0213)\end{array}$ & $\begin{array}{l}0.165 * * * \\
(0.0248)\end{array}$ & $\begin{array}{l}0.104 * * \\
(0.0335)\end{array}$ & $\begin{array}{l}0.111 * * * \\
(0.0296)\end{array}$ & $\begin{array}{l}0.110 * * * \\
(0.0190)\end{array}$ \\
\hline Years 4+ & $\begin{array}{l}0.144 * * \\
(0.0479)\end{array}$ & $\begin{array}{l}0.291 * * * * \\
(0.0633)\end{array}$ & $\begin{array}{l}0.160 * * \\
(0.0570)\end{array}$ & $\begin{array}{l}0.0755 * \\
(0.0319)\end{array}$ & $\begin{array}{c}0.101 * \\
(0.0496)\end{array}$ & $\begin{array}{c}0.0879 \\
(0.0486)\end{array}$ & $\begin{array}{l}0.0879 * \\
(0.0439)\end{array}$ & $\begin{array}{l}0.0713 * * \\
(0.0276)\end{array}$ \\
\hline $\begin{array}{l}\text { F-Test of Equality } \\
\text { p-value of Test }\end{array}$ & $\begin{array}{l}1.179 \\
0.308\end{array}$ & $\begin{array}{c}2.502 \\
0.0819\end{array}$ & $\begin{array}{l}0.838 \\
0.432\end{array}$ & $\begin{array}{l}2.350 \\
0.0954\end{array}$ & $\begin{array}{l}1.836 \\
0.159\end{array}$ & $\begin{array}{l}0.143 \\
0.866\end{array}$ & $\begin{array}{l}0.377 \\
0.686\end{array}$ & $\begin{array}{l}3.485 \\
0.0307\end{array}$ \\
\hline E. Engineering/Indu & & & & & & & & \\
\hline $\begin{array}{l}\text { Main Results } \\
\text { Post-Completion }\end{array}$ & $\begin{array}{l}0.179 * * * \\
(0.0175)\end{array}$ & $\begin{array}{c}0.0659 * * * \\
(0.0120)\end{array}$ & $\begin{array}{l}0.0348 * \\
(0.0153)\end{array}$ & $\begin{array}{l}0.124 * * * * \\
(0.0180)\end{array}$ & $\begin{array}{l}0.218 * * * \\
(0.0158)\end{array}$ & $\begin{array}{l}0.125 * * * \\
(0.0111)\end{array}$ & $\begin{array}{c}0.0769 * * * \\
(0.0147)\end{array}$ & $\begin{array}{c}0.0748 * * * \\
(0.0161)\end{array}$ \\
\hline Step Function & & & & & & & & \\
\hline Years $0-1$ & $\begin{array}{l}0.166 * * * * \\
(0.0161)\end{array}$ & $\begin{array}{c}0.0617 * * * * \\
(0.0111)\end{array}$ & $\begin{array}{l}0.0396 * * \\
(0.0144)\end{array}$ & $\begin{array}{l}0.134 * * * \\
(0.0167)\end{array}$ & $\begin{array}{l}0.202 * * * \\
(0.0148)\end{array}$ & $\begin{array}{l}0.110 * * * \\
(0.0108)\end{array}$ & $\begin{array}{l}0.0804 * * * * \\
(0.0139)\end{array}$ & $\begin{array}{c}0.0540 * * * \\
(0.0159)\end{array}$ \\
\hline Years 2-3 & $\begin{array}{l}0.189 * * * \\
(0.0279)\end{array}$ & $\begin{array}{l}0.0534 * * \\
(0.0186)\end{array}$ & $\begin{array}{l}0.0763 * * \\
(0.0246)\end{array}$ & $\begin{array}{l}0.208 * * * \\
(0.0258)\end{array}$ & $\begin{array}{l}0.252 * * * \\
(0.0231)\end{array}$ & $\begin{array}{l}0.160 * * * \\
(0.0164)\end{array}$ & $\begin{array}{l}0.0669 * * \\
(0.0211)\end{array}$ & $\begin{array}{c}0.0926 * * * * \\
(0.0206)\end{array}$ \\
\hline Years 4+ & $\begin{array}{l}0.246 * * * \\
(0.0478)\end{array}$ & $\begin{array}{l}0.0778 * \\
(0.0330)\end{array}$ & $\begin{array}{l}0.131 * * * \\
(0.0389)\end{array}$ & $\begin{array}{l}0.293 * * * \\
(0.0391)\end{array}$ & $\begin{array}{l}0.259 * * * \\
(0.0427)\end{array}$ & $\begin{array}{l}0.177 * * * \\
(0.0297)\end{array}$ & $\begin{array}{l}0.0818 * * \\
(0.0316)\end{array}$ & $\begin{array}{l}0.136 * * * \\
(0.0305)\end{array}$ \\
\hline F-Test of Equality & 1.867 & 0.752 & 3.885 & 13.21 & 3.976 & 7.183 & 0.467 & 4.574 \\
\hline $\begin{array}{l}\text { p-value of Test } \\
\text { F. IT }\end{array}$ & 0.155 & 0.471 & 0.0206 & 0.000 & 0.019 & 0.001 & 0.627 & 0.0103 \\
\hline Main Results & & & & & & & & \\
\hline Post-Completion & $\begin{array}{l}0.121 * * * \\
(0.0343)\end{array}$ & $\begin{array}{c}0.0659 \\
(0.0638)\end{array}$ & $\begin{array}{c}0.0619 \\
(0.0529)\end{array}$ & $\begin{array}{l}0.0940 * * \\
(0.0326)\end{array}$ & $\begin{array}{l}0.0958 * * \\
(0.0303)\end{array}$ & $\begin{array}{c}0.0887 \\
(0.0627)\end{array}$ & $\begin{array}{c}0.0513 \\
(0.0512)\end{array}$ & $\begin{array}{l}0.0846 * * \\
(0.0299)\end{array}$ \\
\hline Step Function & & & & & & & & \\
\hline Years 0-1 & $\begin{array}{l}0.101 * * * \\
(0.0305)\end{array}$ & $\begin{array}{c}0.0497 \\
(0.0590)\end{array}$ & $\begin{array}{c}0.0730 \\
(0.0473)\end{array}$ & $\begin{array}{l}0.0906 * * \\
(0.0300)\end{array}$ & $\begin{array}{l}0.0813 * * \\
(0.0292)\end{array}$ & $\begin{array}{c}0.104 \\
(0.0558)\end{array}$ & $\begin{array}{c}0.0552 \\
(0.0485)\end{array}$ & $\begin{array}{l}0.0714 * \\
(0.0296)\end{array}$ \\
\hline Years 2-3 & $\begin{array}{c}0.114 * \\
(0.0501)\end{array}$ & $\begin{array}{c}-0.0486 \\
(0.103)\end{array}$ & $\begin{array}{c}0.0258 \\
(0.0739)\end{array}$ & $\begin{array}{c}0.0689 \\
(0.0455)\end{array}$ & $\begin{array}{l}0.128 * * \\
(0.0419)\end{array}$ & $\begin{array}{c}0.0564 \\
(0.0898)\end{array}$ & $\begin{array}{c}0.0334 \\
(0.0667)\end{array}$ & $\begin{array}{l}0.101 * * \\
(0.0380)\end{array}$ \\
\hline Years 4+ & $\begin{array}{c}0.0720 \\
(0.0766)\end{array}$ & $\begin{array}{c}-0.0818 \\
(0.137)\end{array}$ & $\begin{array}{c}0.136 \\
(0.0968)\end{array}$ & $\begin{array}{c}0.116 \\
(0.0668)\end{array}$ & $\begin{array}{c}0.113 \\
(0.0667)\end{array}$ & $\begin{array}{l}0.0834 \\
(0.114)\end{array}$ & $\begin{array}{c}0.0719 \\
(0.0794)\end{array}$ & $\begin{array}{c}0.108 * \\
(0.0550)\end{array}$ \\
\hline F-Test of Equality & 0.445 & 1.098 & 2.810 & 1.014 & 1.157 & 0.258 & 0.298 & 0.464 \\
\hline p-value of Test & 0.641 & 0.334 & 0.0602 & 0.363 & 0.314 & 0.773 & 0.743 & 0.629 \\
\hline
\end{tabular}

Notes: The "main results" correspond to a regression of log earnings on an individual fixed effect, controls for enrollment, and year and age effects. The "step functions" display estimates of the coefficient on three dummy variables for elapsed time since degree or certificate completion, with the omitted category being pre-completion quarters. Standard errors clustered at the individual level. ${ }^{*} p<0.05,{ }^{* *} p<0.01,{ }^{* * *} p<0.001$ 
Table A2: Individual Fixed Effect Results with Trends, Earnings Levels

\begin{tabular}{|c|c|c|c|c|}
\hline & $\mathrm{AA} / \mathrm{AS}$ & 30-59 Units & 18-29 Units & 6-17 Units \\
\hline \multirow[t]{2}{*}{ Health } & $5723.7 * * *$ & $2788.3 * * *$ & $1538.6 * * *$ & $404.8 * * *$ \\
\hline & $(74.14)$ & $(86.71)$ & $(222.1)$ & $(90.84)$ \\
\hline \multirow{2}{*}{$\begin{array}{l}\text { Mean Pre-Earnings } \\
\text { Implied Log Effect }\end{array}$} & 8100.5 & 8147.2 & 8219.7 & 8135.7 \\
\hline & 0.534 & 0.294 & 0.172 & 0.0486 \\
\hline \multirow[t]{2}{*}{ Pub/Prot } & $1119.0 * * *$ & $1063.1 * * *$ & $1694.8 * * *$ & $1164.7 * * *$ \\
\hline & $(90.39)$ & $(110.2)$ & $(124.1)$ & (99.36) \\
\hline \multirow{2}{*}{$\begin{array}{l}\text { Mean Pre-Earnings } \\
\text { Implied Log Effect }\end{array}$} & 11730.4 & 11670.0 & 11695.7 & 11502.9 \\
\hline & 0.0911 & 0.0872 & 0.135 & 0.0964 \\
\hline \multirow[t]{2}{*}{ Bus/Man } & $546.9 * * *$ & 426.1 & $591.9 * * *$ & 367.9 \\
\hline & $(84.61)$ & $(221.8)$ & $(142.2)$ & $(224.3)$ \\
\hline \multirow{2}{*}{$\begin{array}{l}\text { Mean Pre-Earnings } \\
\text { Implied Log Effect }\end{array}$} & 11372.7 & 11414.8 & 11417.4 & 11365.1 \\
\hline & 0.0470 & 0.0366 & 0.0505 & 0.0319 \\
\hline \multirow[t]{2}{*}{ Fam/Cons } & $470.7 * * *$ & $630.6 * * *$ & $334.6 * *$ & $497.6 * * *$ \\
\hline & $(84.02)$ & $(188.5)$ & $(119.3)$ & $(84.83)$ \\
\hline \multirow{2}{*}{$\begin{array}{l}\text { Mean Pre-Earnings } \\
\text { Implied Log Effect }\end{array}$} & 6222.5 & 6241.8 & 6240.1 & 6142.3 \\
\hline & 0.0729 & 0.0962 & 0.0522 & 0.0779 \\
\hline \multirow[t]{2}{*}{ Eng/Ind } & $1213.6 * * *$ & $369.2 * * *$ & 47.80 & $662.7 * * *$ \\
\hline & $(104.3)$ & $(89.32)$ & $(122.0)$ & $(115.4)$ \\
\hline \multirow{2}{*}{$\begin{array}{l}\text { Mean Pre-Earnings } \\
\text { Implied Log Effect }\end{array}$} & 9857.7 & 9837.0 & 9869.9 & 9830.0 \\
\hline & 0.116 & 0.0368 & 0.00483 & 0.0652 \\
\hline \multirow[t]{2}{*}{ Arts } & $835.8 * * *$ & $705.0 *$ & 582.2 & 141.3 \\
\hline & $(252.7)$ & $(274.8)$ & $(363.5)$ & $(519.6)$ \\
\hline \multirow{2}{*}{$\begin{array}{l}\text { Mean Pre-Earnings } \\
\text { Implied Log Effect }\end{array}$} & 11600.7 & 11580.9 & 11609.2 & 11619.8 \\
\hline & 0.0696 & 0.0591 & 0.0489 & 0.0121 \\
\hline \multirow[t]{2}{*}{ IT } & $742.4 * *$ & 580.6 & 55.50 & $457.5 *$ \\
\hline & $(232.5)$ & $(473.5)$ & $(405.5)$ & $(227.0)$ \\
\hline \multirow{2}{*}{$\begin{array}{l}\text { Mean Pre-Earnings } \\
\text { Implied Log Effect }\end{array}$} & 15683.7 & 15718.1 & 15721.5 & 15679.5 \\
\hline & 0.0463 & 0.0363 & 0.00352 & 0.0288 \\
\hline \multirow[t]{2}{*}{ Commercial } & -28.51 & $532.1 * * *$ & $866.8 * * *$ & $671.3 * *$ \\
\hline & $(265.8)$ & $(76.51)$ & $(239.3)$ & $(249.6)$ \\
\hline \multirow{2}{*}{$\begin{array}{l}\text { Mean Pre-Earnings } \\
\text { Implied Log Effect }\end{array}$} & 7709.0 & 7420.5 & 7699.2 & 7713.3 \\
\hline & -0.00371 & 0.0693 & 0.107 & 0.0835 \\
\hline \multirow[t]{2}{*}{ Agr } & $1584.4 * * *$ & $2055.2 * * *$ & 389.3 & 1260.4 \\
\hline & (178.5) & (499.7) & $(314.7)$ & (1717.8) \\
\hline \multirow{2}{*}{$\begin{array}{l}\text { Mean Pre-Earnings } \\
\text { Implied Log Effect }\end{array}$} & 11798.9 & 11865.6 & 11904.9 & 11921.0 \\
\hline & 0.126 & 0.160 & 0.0322 & 0.101 \\
\hline \multirow[t]{2}{*}{ Media/Comm } & $846.7 * * *$ & 772.1 & 831.4 & 527.7 \\
\hline & $(221.5)$ & $(413.2)$ & $(630.2)$ & (396.5) \\
\hline \multirow{2}{*}{$\begin{array}{l}\text { Mean Pre-Earnings } \\
\text { Implied Log Effect }\end{array}$} & 9622.3 & 9642.5 & 9749.1 & 9631.4 \\
\hline & 0.0843 & 0.0770 & 0.0818 & 0.0533 \\
\hline
\end{tabular}

Notes: Each cell corresponds to an individual regression. Sample for each regression consists of students who earned the particular award and qualifying comparison group students, from five years prior to ten years post first enrollment, for students who first enrolled between 2001 and 2005. Outcome variable is quarterly earnings levels. Regressions control for individual fixed effects, age dummies, concurrent enrollment in at least 6 credit hours, year and quarter fixed effects, and individual-specific linear trends. Mean earnings are calculated for the full sample between 0 and 3 years prior to first enrollment. Imputed log earnings transform the percent return into logs. ${ }^{*} p<0.05,{ }^{* *} p<0.01,{ }^{* * *} p<0.001$ 
Table A3: Individual Fixed Effects Results with Trends, Effect on Non-Zero Earnings

\begin{tabular}{lcccc}
\hline & AA/AS & $30-59$ Units & $18-29$ Units & $6-17$ Units \\
\hline Health & $0.152 * * *$ & $0.101 * * *$ & $0.0750 * * *$ & 0.0129 \\
& $(0.00418)$ & $(0.00632)$ & $(0.0136)$ & $(0.00739)$ \\
Pub/Prot & $0.0227 * * *$ & $0.0392 * * *$ & $0.0260 * * *$ & $0.0252 * * *$ \\
& $(0.00599)$ & $(0.00807)$ & $(0.00756)$ & $(0.00435)$ \\
Bus/Man & $0.0193 * * *$ & $0.0572 * * *$ & $0.0522 * * *$ & $0.0423 * * *$ \\
& $(0.00449)$ & $(0.0146)$ & $(0.00922)$ & $(0.0103)$ \\
Fam/Cons & $0.0323 * * *$ & $0.0454 * * *$ & 0.0124 & $0.0359 * * *$ \\
& $(0.00716)$ & $(0.0100)$ & $(0.0109)$ & $(0.00659)$ \\
Eng/Ind & $0.0369 * * *$ & $0.0184 * *$ & -0.00272 & $0.0278 * * *$ \\
& $(0.00782)$ & $(0.00564)$ & $(0.00747)$ & $(0.00798)$ \\
Arts & -0.000917 & $0.0511 * *$ & 0.0457 & $0.0685 *$ \\
& $(0.0141)$ & $(0.0187)$ & $(0.0324)$ & $(0.0317)$ \\
IT & 0.00910 & 0.000324 & 0.0158 & 0.0203 \\
& $(0.0124)$ & $(0.0291)$ & $(0.0215)$ & $(0.0152)$ \\
Commercial & $-0.114 * * *$ & $0.0434 * * *$ & $0.0527 * *$ & 0.00391 \\
& $(0.0179)$ & $(0.00825)$ & $(0.0161)$ & $(0.0203)$ \\
Media/Comm & -0.0170 & 0.0275 & 0.0480 & 0.0336 \\
& $(0.0148)$ & $(0.0217)$ & $(0.0303)$ & $(0.0277)$ \\
\hline
\end{tabular}

Notes: Each cell corresponds to an individual regression. Sample for each regression consists of students who earned the particular award and qualifying comparison group students, from five years prior to ten years post first enrollment. Outcome variable is log quarterly earnings. Regressions control for individual fixed effects, age dummies, enrollment dummies, year and quarter fixed effects, and individual-specific linear trends. Standard errors clustered at the individual level. ${ }^{*} p<0.05,{ }^{* *} p<0.01,{ }^{* * *} p<0.001$ 
Table A4: Robustness Checks, AA/AS

\begin{tabular}{lccccccc}
\hline & $(1)$ & $(2)$ & $(3)$ & $(4)$ & $(5)$ & $(6)$ & $(7)$ \\
& & & Including & Enroll & Same & No & Large \\
& Main & Age 30+ & Transfers & Dummy & Cohort & Control & Control \\
\hline Health & $0.690 * * *$ & $0.645 * * *$ & $0.689 * * *$ & $0.684 * * *$ & $0.690 * * *$ & $0.634 * * *$ & $0.769 * * *$ \\
& $(0.0104)$ & $(0.0153)$ & $(0.00856)$ & $(0.00986)$ & $(0.00989)$ & $(0.0103)$ & $(0.0105)$ \\
Public/Protective & $0.153 * * *$ & $0.152 * * *$ & $0.127 * * *$ & $0.155 * * *$ & $0.155 * * *$ & $0.119 * * *$ & $0.142 * * *$ \\
& $(0.0153)$ & $(0.0321)$ & $(0.0115)$ & $(0.0150)$ & $(0.0150)$ & $(0.0157)$ & $(0.0153)$ \\
Business/Management & $0.140 * * *$ & $0.134 * * *$ & $0.0370 * * *$ & $0.136 * * *$ & $0.136 * * *$ & $0.128 * * *$ & $0.157 * * *$ \\
& $(0.0144)$ & $(0.0235)$ & $(0.00919)$ & $(0.0141)$ & $(0.0141)$ & $(0.0147)$ & $(0.0147)$ \\
Family/Consumer & $0.111 * * *$ & $0.113 * * *$ & $0.0896 * * *$ & $0.115 * * *$ & $0.115 * * *$ & $0.0778 * * * *$ & $0.129 * * *$ \\
& $(0.0183)$ & $(0.0285)$ & $(0.0147)$ & $(0.0180)$ & $(0.0180)$ & $(0.0188)$ & $(0.0184)$ \\
Engineering/Industrial & $0.179 * * * *$ & $0.178 * * *$ & $0.158 * * *$ & $0.184 * * *$ & $0.183 * * *$ & $0.127 * * *$ & $0.155 * * *$ \\
& $(0.0175)$ & $(0.0330)$ & $(0.0158)$ & $(0.0172)$ & $(0.0172)$ & $(0.0176)$ & $(0.0177)$ \\
Fine/Applied Arts & $0.187 * *$ & 0.277 & $0.110 *$ & $0.199 * * *$ & $0.199 * * *$ & $0.184 * *$ & $0.184 * *$ \\
& $(0.0583)$ & $(0.153)$ & $(0.0464)$ & $(0.0578)$ & $(0.0578)$ & $(0.0605)$ & $(0.0576)$ \\
Information Technology & $0.121 * * * *$ & 0.102 & $0.0645 *$ & $0.118 * * *$ & $0.119 * * *$ & $0.123 * * *$ & $0.148 * * *$ \\
& $(0.0343)$ & $(0.0571)$ & $(0.0269)$ & $(0.0343)$ & $(0.0343)$ & $(0.0335)$ & $(0.0354)$ \\
Commercial Services & -0.0483 & -0.0115 & -0.0533 & -0.0467 & -0.0455 & 0.0259 & -0.0141 \\
& $(0.0648)$ & $(0.127)$ & $(0.0533)$ & $(0.0627)$ & $(0.0626)$ & $(0.0681)$ & $(0.0651)$ \\
Agr./Natural Resources & $0.298 * * *$ & $0.355 * * *$ & $0.242 * * *$ & $0.314 * * *$ & $0.316 * * *$ & $0.211 * * *$ & $0.325 * * *$ \\
& $(0.0374)$ & $(0.0762)$ & $(0.0309)$ & $(0.0367)$ & $(0.0368)$ & $(0.0365)$ & $(0.0376)$ \\
Media/Communications & $0.166 * *$ & $0.252 *$ & $0.0802 *$ & $0.161 * *$ & $0.161 * *$ & $0.145 * * *$ & $0.172 * *$ \\
& $(0.0528)$ & $(0.109)$ & $(0.0395)$ & $(0.0520)$ & $(0.0520)$ & $(0.0543)$ & $(0.0539)$ \\
\hline
\end{tabular}

Notes: Each cell corresponds to an individual regression. Sample for each regression consists of students who earned the particular award and qualifying comparison group students, from five years prior to ten years post first enrollment, for students who first enrolled between 2001 and 2005. Outcome variable is log quarterly earnings. Regressions control for individual fixed effects, age dummies, concurrent enrollment in at least 6 credit hours, year and quarter fixed effects, and individual-specific linear trends. Column (1) shows the main result. Column (2) limits sample to students older than 30 at first enrollment. Column (3) includes students who transfer. Column (4) includes a dummy for concurrent enrollment in more than 0 and fewer than 6 credit hours. Column (5) does not limit the treated group to have started in the same cohorts as the comparison group. Standard errors clustered at the individual level. Column (6) does not use a control group. Column (7) uses a single control group, common to all regressions, which is the union of all students in any control group for any TOP code. ${ }^{*} p<0.05, * * p<0.01,{ }^{* * *} p<0.001$ 
Table A5: Robustness Checks, 30-59 Unit Certificates

\begin{tabular}{|c|c|c|c|c|c|c|c|}
\hline & Main & Age $30+$ & $\begin{array}{c}(3) \\
\text { Including } \\
\text { Transfers }\end{array}$ & $\begin{array}{c}(4) \\
\text { Enroll } \\
\text { Dummy }\end{array}$ & $\begin{array}{c}(5) \\
\text { Same } \\
\text { Cohort }\end{array}$ & $\begin{array}{c}\text { (6) } \\
\text { No } \\
\text { Control }\end{array}$ & $\begin{array}{c}(7) \\
\text { Large } \\
\text { Control }\end{array}$ \\
\hline Health & $\begin{array}{l}0.398 * * * * \\
(0.0144)\end{array}$ & $\begin{array}{l}0.399 * * * \\
(0.0227)\end{array}$ & $\begin{array}{l}0.395 * * * * \\
(0.0136)\end{array}$ & $\begin{array}{l}0.395 * * * \\
(0.0136)\end{array}$ & $\begin{array}{l}0.398 * * * * \\
(0.0136)\end{array}$ & $\begin{array}{l}0.396 * * * * \\
(0.0143)\end{array}$ & $\begin{array}{c}0.445 * * * \\
(0.0145)\end{array}$ \\
\hline Public/Protective & $\begin{array}{l}0.154 * * * * \\
(0.0181)\end{array}$ & $\begin{array}{l}0.111 * * * \\
(0.0280)\end{array}$ & $\begin{array}{l}0.157 * * * * \\
(0.0160)\end{array}$ & $\begin{array}{l}0.155 * * * \\
(0.0177)\end{array}$ & $\begin{array}{l}0.154 * * * * \\
(0.0177)\end{array}$ & $\begin{array}{l}0.150 * * * \\
(0.0190)\end{array}$ & $\begin{array}{c}0.141 * * * \\
(0.0181)\end{array}$ \\
\hline Business/Management & $\begin{array}{l}0.109 * * \\
(0.0410)\end{array}$ & $\begin{array}{c}0.0788 \\
(0.0520)\end{array}$ & $\begin{array}{l}0.110 * * \\
(0.0364)\end{array}$ & $\begin{array}{l}0.120 * * \\
(0.0408)\end{array}$ & $\begin{array}{l}0.120 * * \\
(0.0408)\end{array}$ & $\begin{array}{l}0.0925 * \\
(0.0417)\end{array}$ & $\begin{array}{l}0.119 * * \\
(0.0418)\end{array}$ \\
\hline Family/Consumer & $\begin{array}{l}0.195 * * * \\
(0.0272)\end{array}$ & $\begin{array}{l}0.228 * * * \\
(0.0367)\end{array}$ & $\begin{array}{l}0.200 * * * \\
(0.0256)\end{array}$ & $\begin{array}{l}0.198 * * * \\
(0.0262)\end{array}$ & $\begin{array}{l}0.197 * * * \\
(0.0262)\end{array}$ & $\begin{array}{l}0.162 * * * \\
(0.0272)\end{array}$ & $\begin{array}{c}0.209 * * * * \\
(0.0273)\end{array}$ \\
\hline Engineering/Industrial & $\begin{array}{c}0.0659 * * * \\
(0.0120)\end{array}$ & $\begin{array}{l}0.0484 * \\
(0.0220)\end{array}$ & $\begin{array}{c}0.0615 * * * \\
(0.0117)\end{array}$ & $\begin{array}{c}0.0789 * * * \\
(0.0118)\end{array}$ & $\begin{array}{c}0.0760 * * * \\
(0.0118)\end{array}$ & $\begin{array}{c}0.0522 * * * \\
(0.0125)\end{array}$ & $\begin{array}{c}0.0335 * * \\
(0.0121)\end{array}$ \\
\hline Fine/Applied Arts & $\begin{array}{l}0.193 * * * \\
(0.0562)\end{array}$ & $\begin{array}{c}0.253 \\
(0.145)\end{array}$ & $\begin{array}{c}0.194 * * * \\
(0.0523)\end{array}$ & $\begin{array}{c}0.208 * * * \\
(0.0557)\end{array}$ & $\begin{array}{l}0.209 * * * \\
(0.0557)\end{array}$ & $\begin{array}{l}0.179 * * \\
(0.0574)\end{array}$ & $\begin{array}{c}0.201 * * * * \\
(0.0569)\end{array}$ \\
\hline Information Technology & $\begin{array}{c}0.0659 \\
(0.0638)\end{array}$ & $\begin{array}{c}0.0824 \\
(0.0794)\end{array}$ & $\begin{array}{c}0.0733 \\
(0.0586)\end{array}$ & $\begin{array}{c}0.0629 \\
(0.0608)\end{array}$ & $\begin{array}{c}0.0641 \\
(0.0608)\end{array}$ & $\begin{array}{c}0.0982 \\
(0.0698)\end{array}$ & $\begin{array}{c}0.0994 \\
(0.0650)\end{array}$ \\
\hline Commercial Services & $\begin{array}{l}0.184 * * * * \\
(0.0223)\end{array}$ & $\begin{array}{l}0.181 * * \\
(0.0637)\end{array}$ & $\begin{array}{l}0.186 * * * \\
(0.0213)\end{array}$ & $\begin{array}{l}0.181 * * * \\
(0.0206)\end{array}$ & $\begin{array}{l}0.182 * * * * \\
(0.0206)\end{array}$ & $\begin{array}{l}0.192 * * * \\
(0.0232)\end{array}$ & $\begin{array}{c}0.203 * * * * \\
(0.0219)\end{array}$ \\
\hline Agr./Natural Resources & $\begin{array}{l}0.324 * * * * \\
(0.0803)\end{array}$ & $\begin{array}{c}0.349 * * * \\
(0.0866)\end{array}$ & $\begin{array}{l}0.296 * * * * \\
(0.0756)\end{array}$ & $\begin{array}{l}0.309 * * * \\
(0.0774)\end{array}$ & $\begin{array}{l}0.312 * * * \\
(0.0774)\end{array}$ & $\begin{array}{c}0.324 * * * \\
(0.0882)\end{array}$ & $\begin{array}{c}0.345 * * * \\
(0.0800)\end{array}$ \\
\hline Media/Communications & $\begin{array}{c}0.188 * \\
(0.0890)\end{array}$ & $\begin{array}{l}0.393 * \\
(0.175)\end{array}$ & $\begin{array}{l}0.206 * * \\
(0.0784)\end{array}$ & $\begin{array}{c}0.200 * \\
(0.0867)\end{array}$ & $\begin{array}{c}0.200 * \\
(0.0867)\end{array}$ & $\begin{array}{c}0.158 \\
(0.0893)\end{array}$ & $\begin{array}{c}0.197 * \\
(0.0894)\end{array}$ \\
\hline
\end{tabular}

Notes: Each cell corresponds to an individual regression. Sample for each regression consists of students who earned the particular award and qualifying comparison group students, from five years prior to ten years post first enrollment, for students who first enrolled between 2001 and 2005. Outcome variable is log quarterly earnings. Regressions control for individual fixed effects, age dummies, concurrent enrollment in at least 6 credit hours, year and quarter fixed effects, and individual-specific linear trends. Column (1) shows the main result. Column (2) limits sample to students older than 30 at first enrollment. Column (3) includes students who transfer. Column (4) includes a dummy for concurrent enrollment in more than 0 and fewer than 6 credit hours. Column (5) does not limit the treated group to have started in the same cohorts as the comparison group. Standard errors clustered at the individual level. Column (6) does not use a control group. Column (7) uses a single control group, common to all regressions, which is the union of all students in any control group for any TOP code. ${ }^{*} \mathrm{p}<0.05, * * \mathrm{p}<0.01, * * * \mathrm{p}<0.001$ 
Table A6: Robustness Checks, 18-29 Unit Certificates

\begin{tabular}{|c|c|c|c|c|c|c|c|}
\hline & Main & Age $30+$ & $\begin{array}{c}\text { (3) } \\
\text { Including } \\
\text { Transfers }\end{array}$ & $\begin{array}{c}4) \\
\text { Enroll } \\
\text { Dummy }\end{array}$ & $\begin{array}{c}(5) \\
\text { Same } \\
\text { Cohort } \\
\end{array}$ & $\begin{array}{c}(6) \\
\text { No } \\
\text { Control } \\
\end{array}$ & $\begin{array}{c}(7) \\
\text { Large } \\
\text { Control } \\
\end{array}$ \\
\hline Health & $\begin{array}{c}0.278 * * * \\
(0.0296)\end{array}$ & $\begin{array}{c}0.320 * * * \\
(0.0473)\end{array}$ & $\begin{array}{c}0.296 * * * \\
(0.0276)\end{array}$ & $\begin{array}{c}0.259 * * * \\
(0.0261)\end{array}$ & $\begin{array}{c}0.263 * * * \\
(0.0261)\end{array}$ & $\begin{array}{c}0.270 * * * \\
(0.0301)\end{array}$ & $\begin{array}{c}0.306 * * * \\
(0.0296)\end{array}$ \\
\hline Public/Protective & $\begin{array}{c}0.182 * * * \\
(0.0168)\end{array}$ & $\begin{array}{c}0.151 * * * * \\
(0.0298)\end{array}$ & $\begin{array}{c}0.181 * * * \\
(0.0143)\end{array}$ & $\begin{array}{c}0.170 * * * \\
(0.0140)\end{array}$ & $\begin{array}{c}0.169 * * * \\
(0.0140)\end{array}$ & $\begin{array}{c}0.198 * * * \\
(0.0187)\end{array}$ & $\begin{array}{c}0.172 * * * \\
(0.0168)\end{array}$ \\
\hline Business/Management & $\begin{array}{c}0.169 * * * \\
(0.0247)\end{array}$ & $\begin{array}{c}0.174 * * * \\
(0.0304)\end{array}$ & $\begin{array}{c}0.154 * * * \\
(0.0236)\end{array}$ & $\begin{array}{c}0.158 * * * \\
(0.0233)\end{array}$ & $\begin{array}{c}0.158 * * * \\
(0.0233)\end{array}$ & $\begin{array}{c}0.139 * * * \\
(0.0249)\end{array}$ & $\begin{array}{c}0.175 * * * \\
(0.0245)\end{array}$ \\
\hline Family/Consumer & $\begin{array}{l}0.116 * * * \\
(0.0254)\end{array}$ & $\begin{array}{l}0.0771 * \\
(0.0303)\end{array}$ & $\begin{array}{c}0.122 * * * * \\
(0.0236)\end{array}$ & $\begin{array}{l}0.118 * * * \\
(0.0245)\end{array}$ & $\begin{array}{l}0.117 * * * \\
(0.0245)\end{array}$ & $\begin{array}{c}0.0919 * * * * \\
(0.0262)\end{array}$ & $\begin{array}{l}0.126 * * * * \\
(0.0254)\end{array}$ \\
\hline Engineering/Industrial & $\begin{array}{l}0.0348 * \\
(0.0153)\end{array}$ & $\begin{array}{c}0.0405 \\
(0.0247)\end{array}$ & $\begin{array}{c}0.0288 \\
(0.0149)\end{array}$ & $\begin{array}{c}0.0531 * * * * \\
(0.0148)\end{array}$ & $\begin{array}{c}0.0490 * * * \\
(0.0148)\end{array}$ & $\begin{array}{c}0.0108 \\
(0.0152)\end{array}$ & $\begin{array}{c}0.00606 \\
(0.0154)\end{array}$ \\
\hline Fine/Applied Arts & $\begin{array}{c}0.141 \\
(0.120)\end{array}$ & $\begin{array}{c}0.309 \\
(0.278)\end{array}$ & $\begin{array}{l}0.0757 \\
(0.101)\end{array}$ & $\begin{array}{c}0.137 \\
(0.114)\end{array}$ & $\begin{array}{c}0.138 \\
(0.114)\end{array}$ & $\begin{array}{l}0.0817 \\
(0.120)\end{array}$ & $\begin{array}{c}0.139 \\
(0.124)\end{array}$ \\
\hline Information Technology & $\begin{array}{c}0.0619 \\
(0.0529)\end{array}$ & $\begin{array}{c}0.0544 \\
(0.0648)\end{array}$ & $\begin{array}{c}0.0165 \\
(0.0508)\end{array}$ & $\begin{array}{c}0.0833 \\
(0.0530)\end{array}$ & $\begin{array}{c}0.0841 \\
(0.0530)\end{array}$ & $\begin{array}{c}0.0591 \\
(0.0545)\end{array}$ & $\begin{array}{c}0.0819 \\
(0.0539)\end{array}$ \\
\hline Commercial Services & $\begin{array}{l}0.166 * * * \\
(0.0453)\end{array}$ & $\begin{array}{c}0.141 \\
(0.109)\end{array}$ & $\begin{array}{c}0.167 * * * \\
(0.0422)\end{array}$ & $\begin{array}{l}0.175 * * * \\
(0.0405)\end{array}$ & $\begin{array}{l}0.178 * * * \\
(0.0406)\end{array}$ & $\begin{array}{c}0.159 * * * \\
(0.0477)\end{array}$ & $\begin{array}{l}0.188 * * * \\
(0.0449)\end{array}$ \\
\hline Agr./Natural Resources & $\begin{array}{c}0.125 * \\
(0.0558)\end{array}$ & $\begin{array}{c}0.143 \\
(0.0819)\end{array}$ & $\begin{array}{c}0.120 * \\
(0.0547)\end{array}$ & $\begin{array}{l}0.180 * * \\
(0.0570)\end{array}$ & $\begin{array}{l}0.183 * * \\
(0.0570)\end{array}$ & $\begin{array}{c}0.0877 \\
(0.0570)\end{array}$ & $\begin{array}{l}0.146 * * \\
(0.0557)\end{array}$ \\
\hline Media/Communications & $\begin{array}{c}0.220 \\
(0.147) \\
\end{array}$ & $\begin{array}{c}0.110 \\
(0.320) \\
\end{array}$ & $\begin{array}{c}0.198 \\
(0.119) \\
\end{array}$ & $\begin{array}{c}0.206 \\
(0.135) \\
\end{array}$ & $\begin{array}{c}0.206 \\
(0.135) \\
\end{array}$ & $\begin{array}{c}0.244 \\
(0.160) \\
\end{array}$ & $\begin{array}{c}0.199 \\
(0.152) \\
\end{array}$ \\
\hline
\end{tabular}

Notes: Each cell corresponds to an individual regression. Sample for each regression consists of students who earned the particular award and qualifying comparison group students, from five years prior to ten years post first enrollment, for students who first enrolled between 2001 and 2005. Outcome variable is log quarterly earnings. Regressions control for individual fixed effects, age dummies, concurrent enrollment in at least 6 credit hours, year and quarter fixed effects and individual-specific linear trends. Column (1) shows the main result. Column (2) limits sample to students older than 30 at first enrollment. Column (3) includes students who transfer. Column (4) includes a dummy for concurrent enrollment in more than 0 and fewer than 6 credit hours. Column (5) does not limit the treated group to have started in the same cohorts as the comparison group. Standard errors clustered at the individual level. Column (6) does not use a control group. Column (7) uses a single control group, common to all regressions, which is the union of all students in any control group for any TOP code. ${ }^{*} p<0.05,{ }^{* *} p<0.01,{ }^{* * *} p<0.001$ 
Table A7: Robustness Checks, 6-17 Unit Certificates

\begin{tabular}{|c|c|c|c|c|c|c|c|}
\hline & Main & Age $30+$ & $\begin{array}{c}(3) \\
\text { Including } \\
\text { Transfers }\end{array}$ & $\begin{array}{c}(4) \\
\text { Enroll } \\
\text { Dummy }\end{array}$ & $\begin{array}{c}(5) \\
\text { Same } \\
\text { Cohort }\end{array}$ & $\begin{array}{c}\text { (6) } \\
\text { No } \\
\text { Control }\end{array}$ & $\begin{array}{c}\text { (7) } \\
\text { Large } \\
\text { Control }\end{array}$ \\
\hline Health & $\begin{array}{l}0.114 * * * \\
(0.0185)\end{array}$ & $\begin{array}{c}0.122 * * * * \\
(0.0295)\end{array}$ & $\begin{array}{c}0.0947 * * * \\
(0.0165)\end{array}$ & $\begin{array}{l}0.115 * * * \\
(0.0166)\end{array}$ & $\begin{array}{l}0.118 * * * \\
(0.0166)\end{array}$ & $\begin{array}{c}0.135 * * * \\
(0.0197)\end{array}$ & $\begin{array}{c}0.119 * * * * \\
(0.0187)\end{array}$ \\
\hline Public/Protective & $\begin{array}{c}0.140 * * * \\
(0.0126)\end{array}$ & $\begin{array}{c}0.110 * * * \\
(0.0233)\end{array}$ & $\begin{array}{l}0.131 * \\
(0.010\end{array}$ & $\begin{array}{c}0.143 * * * \\
(0.0111)\end{array}$ & $\begin{array}{c}0.142 * * * \\
(0.0111)\end{array}$ & $\begin{array}{c}0.116 * * * \\
(0.0139)\end{array}$ & $\begin{array}{c}0.133 * * * * \\
(0.0125)\end{array}$ \\
\hline Business/Management & & & & & & $\begin{array}{c}0.155 * * * \\
(0.0291)\end{array}$ & $\begin{array}{c}0.172 * * * * \\
(0.0281)\end{array}$ \\
\hline Family/Consumer & & $\begin{array}{c}0.101 * * * \\
(0.0217)\end{array}$ & & & & & \\
\hline Engineering/Industrial & $\begin{array}{l}0.124 * * * \\
(0.0180)\end{array}$ & $\begin{array}{c}0.157 * * * \\
(0.0273)\end{array}$ & $\begin{array}{l}0.123 \\
(0.01\end{array}$ & $\begin{array}{l}0.133 * * * \\
(0.0163)\end{array}$ & $\begin{array}{l}0.130 * * * \\
(0.0163)\end{array}$ & $\begin{array}{c}0.0939 * * * \\
(0.0185)\end{array}$ & $\begin{array}{c}0.117 * * * * \\
(0.0182)\end{array}$ \\
\hline Fine/Applied Arts & & & & & & & \\
\hline Information Technology & $\begin{array}{c}0.0940 * * \\
(0.0326)\end{array}$ & & & $\begin{array}{c}0.0949 * * \\
(0.0307)\end{array}$ & $\begin{array}{c}0.0957 * * \\
(0.0307)\end{array}$ & & \\
\hline Commercial Services & & $\begin{array}{l}0.395 * * \\
(0.132)\end{array}$ & $\begin{array}{c}0.155 * \\
(0.0613)\end{array}$ & $\begin{array}{c}0.206 * * * \\
(0.0523)\end{array}$ & $\begin{array}{c}0.208 * * * \\
(0.0522)\end{array}$ & $\begin{array}{c}0.257 * * * \\
(0.0683)\end{array}$ & $\begin{array}{l}0.191 * * \\
(0.0656)\end{array}$ \\
\hline Agr./Natural Resources & $\begin{array}{c}0.0337 \\
(0.0923)\end{array}$ & $\begin{array}{c}-0.00396 \\
(0.127)\end{array}$ & $\begin{array}{l}-0.00453 \\
(0.0873)\end{array}$ & $\begin{array}{c}0.0719 \\
(0.0892)\end{array}$ & $\begin{array}{c}0.0735 \\
(0.0894)\end{array}$ & $\begin{array}{c}-0.00973 \\
(0.0990)\end{array}$ & $\begin{array}{c}0.0559 \\
(0.0942)\end{array}$ \\
\hline & $\begin{array}{c}0.143 \\
(0.115)\end{array}$ & $\begin{array}{c}0.177 \\
(0.202)\end{array}$ & $\begin{array}{c}0.122 \\
(0.103) \\
\end{array}$ & $\begin{array}{c}0.136 \\
(0.106)\end{array}$ & $\begin{array}{c}0.136 \\
(0.106) \\
\end{array}$ & $\begin{array}{c}0.135 \\
(0.113) \\
\end{array}$ & $\begin{array}{c}0.155 \\
(0.117) \\
\end{array}$ \\
\hline
\end{tabular}

Notes: Each cell corresponds to an individual regression. Sample for each regression consists of students who earned the particular award and qualifying comparison group students, from five years prior to ten years post first enrollment, for students who first enrolled between 2001 and 2005. Outcome variable is log quarterly earnings. Regressions control for individual fixed effects, age dummies, concurrent enrollment in at least 6 credit hours, year and quarter fixed effects, and individual-specific linear trends. Column (1) shows the main result. Column (2) limits sample to students older than 30 at first enrollment. Column (3) includes students who transfer. Column (4) includes a dummy for concurrent enrollment in more than 0 and fewer than 6 credit hours. Column (5) does not limit the treated group to have started in the same cohorts as the comparison group. Standard errors clustered at the individual level. Column (6) does not use a control group. Column (7) uses a single control group, common to all regressions, which is the union of all students in any control group for any TOP code. ${ }^{*} p<0.05, * * p<0.01,{ }^{* * *} p<0.001$ 